\title{
Urbanisation-induced Displacements in Peri-urban Areas: Clashes between Customary tenure and Statutory Practices in Ugbo-Okonkwo Community in Enugu, Nigeria
}

\begin{abstract}
Rapid urbanisation is precipitating wide-ranging and often irreversible changes in cities and at the shifting peri-urban areas around the world. As a significant factor of change in the $21^{\text {st }}$ Century, urbanisation is irreversibly transforming everything on its path-air, land, water, and ecology, including institutions, customs, and lifestyles. The subject scope of urbanisation research is therefore quite wide and diverse. Yet, urbanisation-induced attritions and substitutions of customary tenure practices, coupled with the associated politics and resistances, remain utterly overlooked. Using a mixed method approach (involving desktop research, remote sensing data and stakeholder interviews), this paper examines the clashes between customary tenure regime and statutory practices dictated by urban laws, and how different stakeholders are appropriating them both to promote and resist displacement or eviction. Amidst growing encroachment pressures on peri-urban communities in Nigerian cities, a new imperative for enhanced tenure security and integrated planning approach are proposed.
\end{abstract}

Keywords: urbanisation; urban-induced attritions; conflict; customary tenure; statutory tenure; Enugu, Nigeria

As a city grows outwards, so too does the footprint of statutory law. This often results in clashes between local authorities and traditional leadership. This conflict reflects a wider set of tensions within the country and should be treated with care (Berrisford \& McAuslan, 2017, p. 20)

\section{Rapid Urbanisation and its new Fault-line}

Notwithstanding the orchestrated development outlook of urbanisation and the mega-city phenomenon (Glaeser, 2014), emerging evidence in global urbanisation and customary tenure studies are revealing serious challenges in contemporary urban dynamics. As one of the "most significant form of land-use and land-cover change" (Haase, Güneralp, Dahiya, Bai, \& Elmqvist, 2018, p. 25), urbanisation manifests in continuing demographic transition and spatial expansion (or peri-urbanisation). This is linked to peri-urban and rural areas through crossexchanges, or rural-urban 'flows', of people, capital, information, raw materials, food, water, etc. (Allen, Brown, Dávila, \& Hofmann, 2015). Urbanisation through complex dynamics tend to irreversibly change everything on its path-air, land, water, and ecology, including institutions, customs, and lifestyles, thereby opening a diverse and widening scope for urbanisation research towards sustainability and mutually beneficial outcomes for urban and rural regions (Elmqvist et al., 2013; Bai et al., 2014; Allen et al., 2015; Berrisford \& McAuslan 2017; Vij, Narain, Karpouzoglou, \& Mishra, 2018). Consequently, in "peri-urban areas, or 
newly urbanising areas, hybridised forms of local regulation, which draw on both customary and statutory laws are emerging" (Berrisford \& McAuslan, 2017, p. 20). They retain a heterogeneous mix of social and economic outlays, land use, and densities, and are often in constant state of flux with little or no coherent planning and policy intervention (Mabin, Butcher \& Bloch, 2013; Sawyer, 2014, p. 275; Bartels, 2019). Although panaceas for the lessthan-desirable outcomes of rapid urbanisation - from urban containment (Arku, 2009), building reciprocal rural-urban linkages and integrated planning perspectives (Allen et al., 2015), to global sustainability agenda (UN-Habitat, 2016) - have recorded appreciable successes in some contexts, the overall challenges remain very daunting.

African and Asian cities have among the fastest growth rates in the world (UN DESA, 2018), and as a result, are experiencing opportunities and risks associated with rapid urbanisation and megacity proliferation (Allen et al., 2015; Bah, Faye \& Geh, 2018). In line with the opening quote, urbanisation is conceived in this article mainly in terms of peri-urbanisation or urban expansion, resulting in hybrid transitional landscapes with urban and rural peculiarities. It is notable that "expansion of cities across Africa is accentuating the clash between customary and statutory land tenure systems and cultures" (Bah et al., 2018, p. 131). Customary tenures constitute over $80 \%$ of the entire landholding on the continent, and are the system of landholdings which "most rural African communities operate to express and order ownership, possession, and access, and to regulate use and transfer" (Alden Wily, 2011, p. 1). Notwithstanding past research and programme efforts at promoting reciprocal urbanisation in order to guarantee mutual benefits for urban, peri-urban, and rural regions (Allen et al., 2015), urbanisation-induced attritions and substitutions of customary tenure regimes have however remained unremitting.

Even worse, the politics and resistances associated with these occurrences continue to be overlooked in urbanisation research. For instance, out of 25 identifiers ${ }^{1}$ isolated by Wang et al. (2012) in their systematic analysis of 8,569 urbanisation articles published between 1991 and 2009, nothing at all appeared for customary land tenure. Could such yawning gaps have stemmed from what Sawyer (2014, p. 237) described as "the exclusion or, at least, omission of

\footnotetext{
${ }^{1}$ Identifiers constitute most frequently used terms in the titles, abstracts, and keywords. The terms and counts isolated by Wang et al. (2012) include: urbanisation (1,802), USA (540), land-use (490), urban (327), patterns (281), conservation (280), China (263), population (253), growth (252), biodiversity (245), cities (234), model (233), prevalence (231), city (229), health (222), management (211), landscape (205), and mortality (205). Others are pollution (195), epidemiology (191), ecology (189), diversity (186), GIS (183), migration (181), and impact (173).
} 
African cities from the conceptual landscape of urbanisation at the periphery"? This is probable even though the remit is outside our current scope. A more plausible and relevant answer appears to lie in current ideations that planetary or global urbanisation is "posited at too high a level of abstraction to directly analyse changes on the ground" (Khan \& Karak, 2019, p. 2). Consequently, the research radar fails to capture diverse plights and struggles of customary communities for "survival in a world where non-customary systems dominate" with all the inherent dispossessory twists (Alden Wily, 2016, p. 458). Not only do urban-centred statutory practices dictated by urban laws (such as formal tenure rules, planning regulations, among others) threaten vast customary lands in peri-urban Africa, community livelihoods and survival that depend on these 'indigenous and foundational land laws' also face grave risks (McAuslan, 2006, p. 9). Thus, reinforcing the elusive connection between rapid urbanisation and loss of cultural heritage or property (Wiersma, 2004; Duxbury, Hosagrahar \& Pascal, 2016).

Drawing on a larger research on urban infrastructure-related displacements under the Urban Research Nigeria funded by UK DFID between 2016 and 2017, this article examines the halted eviction at Ugbo-Okonkwo, one of several customary communities on the urban expansion pathways of Enugu capital city, Enugu State, Nigeria. The case study is used as a channel to interrogate the clashes pervading attritions/substitutions of customary tenure regime by statutory practices aided by urban laws as cities expand; and how different stakeholders are appropriating them both to promote and resist displacement in the peri-urban areas of Nigeria. Although the Land Use Act of 1978 (hereafter LUA-1978) chronicles the rules and principles of statutory land tenure in Nigeria, it has only a passive recognition for the oral-based and court-codified customary tenure regime (Nwauche, 2010; Tagliarino, Bununu, Micheal, De Maria \& Olusanmi, 2018). The current approach attempts to epitomise an archetypal urbanisation-induced 'changes on the ground', which Sawyer (2014) has likened to incorporating inherent fluxes or dynamic processes at the peripheries. It also aims to showcase the intriguing planning and politics of customary land dispossession, and the opposing social resistance by affected residents in a rapidly growing Nigerian city. The research hopes to contribute to differentiated understanding (or gradients) of urban peripheries and periurbanisation, and expectedly, unlock the grave consequences of piece-meal planning, issues that remain vaguely explored in Nigerian/African urban thought (Sawyer, 2014). Two specific but related objectives pursued in this research are, to: one, assess the urban encroachment scenarios as it affects this peri-urban community and the members' affective/discursive 
outlook; and two, explore the nature of customary-statutory tenure conflicts, politics and power relations in land expropriations, and countervailing resistance struggles.

\section{Urbanisation as a dispossessory thrust in City Sprawl/ Rural Shrinkage Process}

\subsection{Widening impacts of transformative urbanisation and emergent research gap}

Global (or planetary) urbanisation research has opened a new all-inclusive layer in urban studies that transcends local, even national manifestations of urbanisation. This shift has also expanded the meaning of urbanisation from demographic transition and spatial expansion (sprawl) to include connectivity and flows of people, goods (land rights, water, raw materials, manufactured products, waste, etc.), money and information across rural and urban domains (Berdegué, Proctor with Cazzuffi, 2014). This emerging perspective has afforded us better insights into urbanisation-induced impacts on diverse and expansive issues like natural resource depletion, land cover changes and biodiversity reduction, teleconnections, material and energy flows, institutional transformation, distortion of network and power hierarchy, etc. (Wang et al., 2012; Scheuer, Haase \& Volk, 2016; Haase et al., 2018). Notwithstanding inherent allusions to comprehensiveness, global urbanisation research still pays little or no attention to urbanisation-induced attrition or erosion of customary tenure systems, thereby obscuring the plights and resistances of many customary communities. Quite recently, Chimhowu (2019, p. 901) has termed this rising phenomenon the 'structural transformation and gentrification of customary lands' in Africa, whose central logic boils down to:

...displacement of poor people from their land through distress sales and in some cases through simple land grabbing by local elites working with state officials or investors especially in jurisdictions where customary tenure still does not offer statutory protection.

Indeed, ongoing rapid shrinkage of global reservoir of customary landholdings - whether induced directly by urban expansion or in combination with other factors such as land individuation and commodification, and infrastructure projects - deserves serious attention for two reasons. One, the sheer staggering size of customary lands in Africa (estimated at six billion hectares) and the fact that approximately three billion people or $40 \%$ of the world population depend on them for habitation and livelihoods (Alden Wily, 2018a). Two, attrition of customary landholdings also constitute a loss to cultural property that threatens bonds of unity in most customary communities, thereby derailing the prospects of sustainable development (Duxbury, et al., 2016). These issues constitute a big lag in the prospects of achieving sustainable development goals. Meanwhile, rapid urbanisation, through a process 
Bartels (2019, p. 4) termed 'quiet encroachment', continues to engulf more and more communities and villages on its path (compare with Berrisford \& McAuslan, 2017, p. 20; Bah, et al., 2018, p. 131).

But why is rapid urbanisation - a key factor of socio-economic, cultural and spatial/land use transformation - implicated in this suppression of customary lands? Two major reasons easily come to mind. First, prevailing legal and institutional orthodoxies often tend to privilege cities (and their needs) over those of surrounding peri-urban villages (Vij et al., 2018, p. 389). This is connected, on the one hand, to the current capitalist or neoliberal economic regime, which is constitutive of the ongoing 'neo-liberalisation of customary tenure' in Africa (Chimhowu, 2019, p. 898), and to subsisting power asymmetries that esteem customary land interest as less than property, on the other (Alden Wily, 2016). Second, contemporary urbanisation has become synonymous with 'primitive accumulation' or those development propensities and dispossessory tendencies implicated in worsening inequality and poverty across urban and rural realms across the world (Harvey, 2007; Sherman, 2016; Khan \& Karak, 2019). In other words, the legal and planning apparatuses that shape urbanisation appears to unduly favour land grabbing by government and other powerful actors have become a major source of conflicts in Nigerian and other African cities (Tagliarino et al., 2018; Boone, 2019; Agheyisi, 2019a). The above-mentioned factors are exacerbated by subsisting planning and policy voids in the periurban areas (Allen, et al., 2015). Consequently, “...peri-urban conflicts are rooted in the issue of land-use change and are fundamentally tied to the politics of urbanisation and its impact on peri-urban areas" (Vij et al., 2018, p. 382).

\subsection{Shifting rural-urban interface, urban encroachment, and tenure-related conflicts}

Customary land uptake for suburbanising African cities is now becoming a part and parcel of the 'vicious cycle' of rural deprivation and subjugation, loss of cultural property, and periurban conflicts with the unsavoury prospects of retarding economic investment (Wiersma, 2004; Ubink, 2007; Turok, 2016). Turok (2016, p. 36) sees urbanisation as a core driver of customary tenure attritions and tenure-related conflicts:

Conflicts are most apparent where there is strong pressure for land as cities encroach upon the countryside. These clashes are frequently driven by the sizeable uplift in land values as rural land is converted to urban. In many cities there have been evictions of poor communities who thought they had rights to the land, only to discover that someone else apparently had a more legitimate claim. 
Urbanisation actually signifies spatio-temporal encroachment on peri-urban lands with concomitant impacts that can over time lead to wider conflicts (Figure 1). Unlike Turok (2016) and scholars like Berrisford \& McAuslan (2017) and Bartels (2019), who take a basically 'encroachment' approach to tenure-related conflict, Allen et al. (2015) and Agheyisi (2019a), for example, espouse a more systematic approach characterised by pervading rural-urban flows and interactions for reciprocal benefits. By bringing together in sharp relief some contrasting and unequal attributes of urban and rural worlds - tenure systems, laws, institutions, and authorities - urbanisation interfaces with the urban land market to set the stage for the neocustomary tenure system (Onyebueke \& Ikejiofor, 2017; Agheyisi, 2019a, 2019b). In what Agheyisi (2019a, p. 532) described as "socio-cultural environment of urban land market and local power relations", local communities and other stakeholders, such as public planning agencies, and private developers, interact for mutual benefits and exchanges. End products are usually in form of community tracts, parcellated lands, monies, titles, and building permits with the intervening official and socio-cultural compromises. Albeit riddled with land corruption, rent-seeking behaviours, speculations and exploitations of land value capture (Bah, et al., 2018, pp. 29-30), conflict situations often result from unwarranted evictions and other disruptions to these tenuous, informally-reached practices.

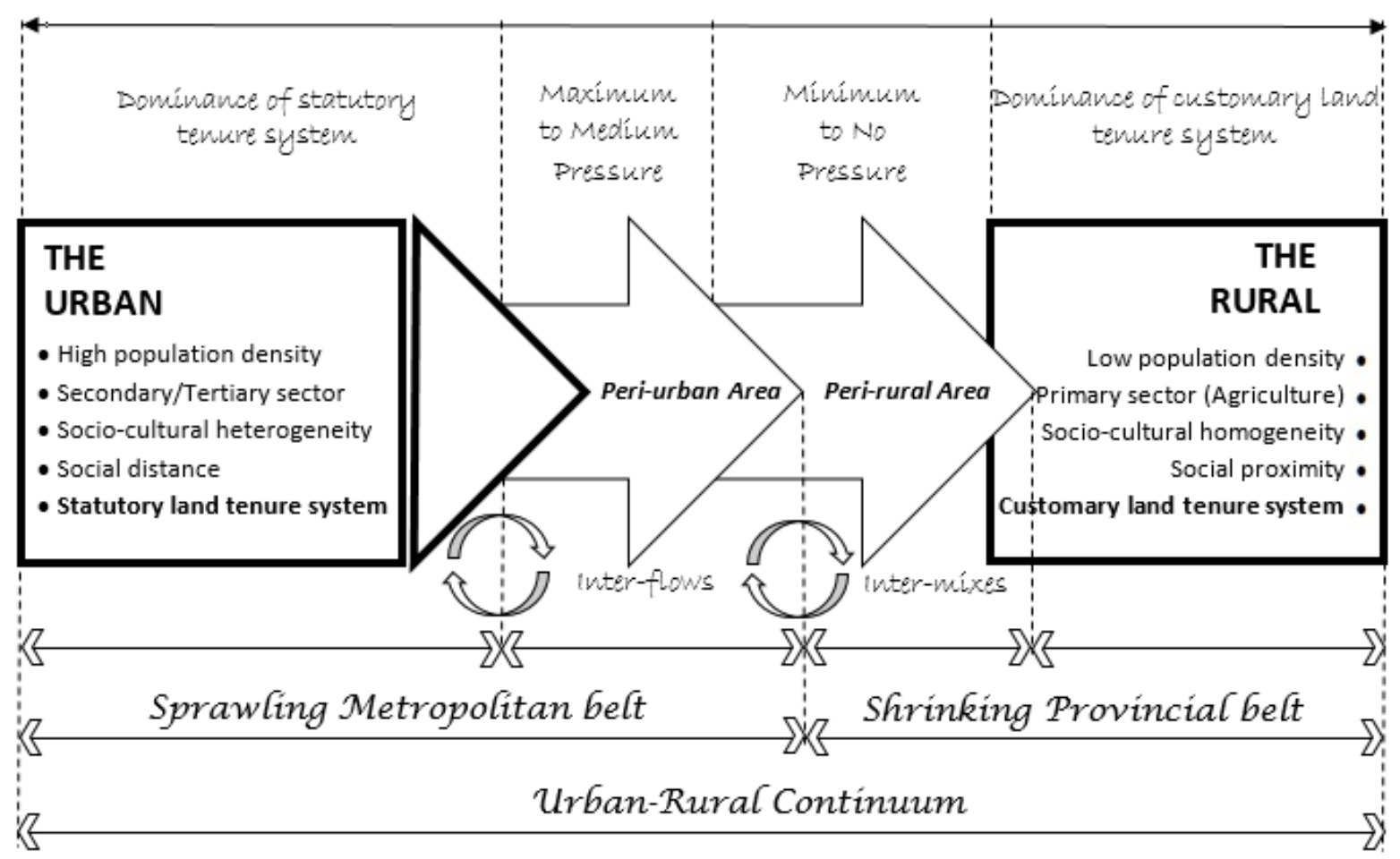

Figure 1. Sprawl-shrinkage dynamics in the urban-rural continuum and changing pressure on customary tenure system (Authors' illustration). 
Peri-urban landscapes in Lagos and many other African cities have been likened to a mishmash of land tenures, administrative regulations, and piece-meal planning (Sawyer, 2014; Lamond, Awuah, Lewis, Bloch, \& Falade, 2015). In some areas, customary tenures have been substituted while in others, they are juxtaposed with their statutory equivalents in form of legal pluralism (Otto \& Hoekema, 2012; Berrisford \& McAuslan, 2017; Bah, et al., 2018, p. 111). Possibly in most peri-urban contexts, they are witnessing a neo-customary turn - the increasingly adaption to land market pressures through community co-produced land subdivisions with assorted socio-economic and institutional transformations (Onyebueke \& Ikejiofor, 2017; Chimhowu, 2019). According to Berrisford \& McAuslan (2017):

The way a country's constitution accommodates the powers of traditional leaders and the status of customary law affects urban law, especially in peri-urban areas, where expanding cities encroach on areas that have historically been under the custodianship of traditional leaders (p. 20).

These occurrences, involving "extension of state power into areas it had limited influence", are a source of outspreading of urban law jurisdictions with implications for serious conflicts of interest and power (Chimhowu, 2019, p. 901). Berrisford and McAuslan (2017) contextualised urban laws as rules "used for governing, planning, managing and financing African cities" (p. 2). Out of 54 African countries, only 9 countries (about 17\%) have urban laws that guarantee strong support or protection for customary tenure systems, and the other 45 countries (or 83\%), including Nigeria, have moderate to minimal support, or no support at all (Alden Wily, 2018b). Table 1 shows a profile of customary law protection regime in a number of African countries.

Table 1. National legal architecture and differing supports for customary properties in Africa

\begin{tabular}{l}
\hline STRONG SUPPORT (16.6\%) \\
\hline Uganda, Tanzania, Kenya, Mozambique, South Sudan, Burkina Faso, Ghana, Mali, and Malawi \\
\hline MEDIUM SUPPORT (with either one or two significant limitations) (38.9\%) \\
\hline $\begin{array}{l}\text { Angola, Namibia, Swaziland, Lesotho, Sierra Leone, Gambia, Guinea, Ethiopia, Zambia, Benin, } \\
\text { Togo, Namibia, Tunisia, Morocco, Algeria, Niger, Madagascar, Botswana, Ivory Coast, and Nigeria }\end{array}$ \\
\hline POSSIBLE SUPPORT (with more than two significant limitations) (26\%) \\
\hline $\begin{array}{l}\text { Egypt, Mauritania, Cape Verde, Guinea Bissau, Senegal, Sudan, Chad, Cameroon, Gabon, DRC, } \\
\text { Congo Brazzaville, Mauritania, Zimbabwe, and Equatorial Guinea. }\end{array}$ \\
\hline MINIMAL OR NO SUPPORT (14.8\%) \\
\hline Burundi, Rwanda, Eritrea, Seychelles, Mauritius, Somalia, Comoros, and Central African Republic \\
\hline INSUFFICIENT DATA (3.7\%) \\
\hline Djibouti, and Sao Tome \& Principe \\
Source: Compiled from Alden Wily (June 2018) Community Property in Africa. Brief No. 2. The Rights and \\
Resources Coalition, p. 7. https://www.forestpeoples.org/sites/default/files/documents/Brief\%202\%20- \\
\%20Community\%20Property\%20in\%20Africa.pdf
\end{tabular}


Price $(2015$, p. 678) is however of the view that "(e)ven where country legal frameworks explicitly recognise customary rights" there are no guarantees such rights may not be flouted in practice. As such, displacements and associated conflicts are not ruled out completely. Around the world, land tenure-related conflicts in peri-urban areas are known to arise from three main sources: conflicts of interests between individuals, groups and institutions (55\%); conflicts of power - coercive exercise of power and the countervailing grassroots resistance (24\%); and legal and normative conflicts, relating to divergent context, procedure, and function of customary and formal land tenure system (21\%) (Dadashpoor \& Somayeh, 2019). Peri-urban areas can therefore be rightly thought of as 'politicised environments' characterised by both land/resource conflicts and resistance practices (Vinthagen \& Johansson, 2013), where judicious interventions could lead to 'new forms of cooperation' (Vij et al., 2018, p. 383). Scholars have attributed such beneficial outcomes to reforms that incorporate enhanced tenure security (Otto \& Hoekema, 2012; Alden Wily, 2018a; Boone, 2019) as well as integrated planning solutions (Allen et al., 2015). While the former option aims to empower customary landholders and the poor through property rights determination, the latter seeks to integrate urban, rural, and regional perspectives of planning in a way that respects enterprise, livelihood, and reciprocal flows between the urban, peri-urban, peri-rural, and rural domains (see Figure 2). Allen et al. (2015, p. 22) have in mind the inauguration of "more effective and equitable planning systems designed with the needs, priorities and affordability requirements of the poor and those straddling between urban and rural areas in mind".

PLANNING PERSPECTIVES

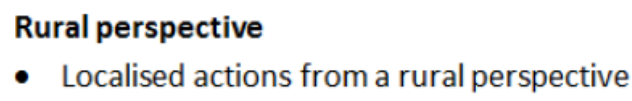

- Localised actions from a rural perspective

\section{Regional perspective}

- Acting on flows and pressures

Urban perspective

- Transforming urban planning systems

- Localised actions from an urban perspective

\section{INTERVENTION AREAS}

Decentralised water and sanitation

Micro-credit

Land-based livelihoods

Natural resources management

Urban and rural economic enterprises

Urban-rural market information

Food supply and distribution to cities

Urban and peri-urban agriculture

Urban impacts and ecological footprints

Urban planning and management systems

Transport and land use

Land regularization and housing

Infrastructure and sanitation

Health and pollution

Figure 2. Planning perspectives and intervention areas (Allen et al., 2015, p 11). 
Land or place-based struggles typify collective initiatives of the poor and marginalised populations against power relations that both disempower and impoverish them (Deveaux, 2018; Martiniello, 2019). Both displacement scholars and political/democratic theorists are on common grounds with the Foucauldian notion that " $(\mathrm{w})$ here there is power, there is resistance, and $\ldots$ this resistance is never in a position of exteriority in relation to power" (Foucault, p. 95). In many contexts, 'everyday resistance' or grassroots resistance (including strategies like street protests, picketing, direct confrontation, negotiations, even legal battles, etc.) have afforded countless actual/potential evictees cheering respites (and on occasions, full remedy or redress), which led Cabannes, Yafai and Johnson (2010, p. 3) to conclude that "people-led movements are a fundamental ingredient to successful solutions to forced evictions". However, success frequently depends on the strength of community solidarity and capacity to stir up "inter-elites rivalry and cleavages within structures of authority (state and traditional authorities)" (Martiniello, 2019, p. 196). At this juncture, it is pertinent to contextualise sources (in law and practice) of inter-tenure conflicts and attendant clashes in Nigeria.

\subsection{Origins of Nigeria's dual tenure system and customary-statutory conflicts}

Like in other African countries, Nigeria's dual tenure structure - consisting of customary or indigenous tenure and statutory tenure systems - is a heritage of colonial rule. In the territory now known as Nigeria, diverse systems of unwritten but practical rules of rights and obligations pertaining to land ownership and use had existed among different ethnicities long before British colonisation. With the advent of colonial administration, the statutory or formal tenure system was introduced exclusively for designated urban areas between 1861 and 1917 (see Onyebueke \& Ikejiofor, 2017). This phase coincided with enactments that put the defunct Lagos Protectorate under the Crown Land freehold principles of the English Common Law in 1861 (ratified as Public Lands Ordinance of 1903), the Land and Native Proclamation Ordinance of 1908 in Northern Nigeria, and the Public Lands Ordinance of 1903 (later ratified as Public Lands Acquisition Act of 1917) in Southern Nigeria. These early statutes facilitated land acquisition for public projects and (re)settlement of colonial workforce since prevailing customary rules only bestowed use-right transfers (through land pledging, land gift and land borrowing) without permitting land alienation to non-natives (Dike, 1983). The manifest urban bias of colonial land statutes instigated the contentious tenure dichotomy between urban and rural areas that has continued till date in the country. Colonial urban planning also took the same legislative route with similar effects on present-day 'piecemeal' planning practices that arbitrarily extend urban laws and visions to the hinterlands (Lamond et al., 2015). Several 
public health acts culminated in the Town and Country Planning Law of 1946, which itself was later replaced by the Nigerian Urban and Regional Planning Law of 1992.

After independence in 1960, the need to consolidate divergent land tenures in the country became paramount, and a land nationalisation law, the LUA-1978 (Land Use Act of 1978), came into force. The Act vests all lands within the territories of various states (except those owned by the federal government and its agencies) in the governors, and "such land shall be held in trust and administered for the use and common benefit of all Nigerians in accordance with the provisions of this Act" (Part I, S. 1). This overreaching oversight, notwithstanding, state governors are only empowered to control and manage urban lands, in consultation with the stipulated 5-member Land Use and Allocation Committee. In principle, these functions exclude oversight over rural lands that falls under the jurisdictional control and management of local government areas to be guided by the proposed Land Allocation Advisory Committees. In discharging these duties, the latter are supposed to grant customary right of occupancy (CRO) for rural tracts, whereas the governors issue statutory right of occupancy (SRO) for urban tracts as well as revoke both CRO and SRO for 'overriding public interest'. Also, the LUA-1978 requires state governors to endorse the devolutions of CRO to the heir(s) apparent in accordance with applicable customary laws $(\mathrm{S} .24,1 \mathrm{~b})$ as well as to recognise communal land ownership, particularly the guardianship roles of chiefs, community leaders, and community-based organisations over customary lands (S. 29, ss. 3a \& b).

However, in practice, key sticking points remain in the myriad operational co-existence of customary and statutory tenure rules. There are innumerable pointers and sources of intertenure conflicts ${ }^{2}$ because “....although the LUA-1978 seems to recognise the indigenous land tenure, it nonetheless fails to make clear and adequate provisions for it" (Oshio, 1990, p. 61). Two key clashes related to the current enquiry have persisted a subject of heated litigations and protests in Nigeria. First is the contested nature of the 'overriding public interest' doctrine that harbours contrasting meanings for different players in real-life situations of land expropriation and eviction (Tagliarino et al., 2018; Onyebueke, Walker, Lipietz, Ohaeri, \& Ujah, 2019). The other is the equally disputed question of customary tenancy. This distinct tenancy rule involves

\footnotetext{
${ }^{2}$ Another problem is that the transitional provisions of the Act do not set deadlines for the conversion of formerly indigenous titles into rights of occupancy. Consequently, the indigenous title holders feel that they are free to deal with their land parcels or alienate them in accordance with customary law even in disregard of the rights of occupancy system.
} 
the customary grantor (overlord or landlord) and the customary tenant(s), who under customary tenure is/are considered as either lessee(s) or borrower(s) per se, but "grantee(s)". Essentially, a grantee of customary land "holds a determinable interest in the land which may be enjoyed in perpetuity subject to good behaviour on the part of the tenant" (Oshio, 1990, p. 47). The 'good behaviour' tenet translates into several obligations such as yearly payment of tributes to customary grantors as a reaffirmation of tenancy relations, continue use of allotted lands for the granted purpose(s), shared commitment neither to alienate nor retract said lands without mutual consent, and land abandonment or repudiation of ascribed ownership titles of customary grantors (Nwauche, 2010).

Nowadays, outright forfeiture of customary tenancies, which have managed to survive to this day, is now controversial for at least two reasons. The first one is that Section 36(2) of the LUA-1978 only grants customary tenants the status of 'occupiers', and as such, they remain tenants of the local government and prospective recipients of the customary right of occupancy (Oshio, 1990; Nwauche, 2010). The second reason is that although conflicting court rulings and legal controversies abound on the subject matter, succeeding court decisions appear to favour the legal dictum that 'possession is nine-tenths of the law' (Oshio, 1990, p. 59-60). Based on the Lagos Free Trade Zone Project in which government expropriated 16,500 hectares of farmlands from about nine indigenous communities, Tagliarino et al. (2018, p. 32) have concluded that the LUA-1978 has been ineffective in protecting local land rights. They warned that, if not amended, it "will continue to subject affected communities to impoverishment, landlessness, food insecurity, and other risks commonly associated with expropriation for development projects."

\section{Case Study Selection and Methods}

\subsection{Enugu: the Capital City of Enugu State, Nigeria}

Enugu is the capital of Enugu State, and a key administrative centre in South-east Nigeria (Figure 3). The city began as a proto-urban centre with discovery of coal in the area in 1907. Growing as a mineral town under the British colonial administration, Enugu became headquarters designate of Eastern Nigeria in 1936. With successive demarcations of administrative boundaries in Nigeria, it retained its status as seat of government in the former Eastern Region (1936-1967), defunct secessionist Biafra (1967-1969), East-central State (1970-1976), old Anambra State (1976-1991), and Enugu State (1991 to date). Over the years, 
Enugu grew from a built-up area of nearly $56,000 \mathrm{Km}^{2}$ in 1986 to approximately $126,000 \mathrm{Km}^{2}$ in 2015 (Onyebueke \& Ndukwu, 2017). Simply put, the city more than doubled in size in last 29 years. Its outward expansion has progressed in tandem with the replacements of customary land holdings through sequences of piecemeal land acquisitions, grabbing, and purchases that have left vestiges of customary communities within and beyond its boundaries. Prominent among these 'customary communities' are Ogui Nike, Ogui Urban, Ugbo-Okonkwo in City Layout, Ugbo-Odogwu in Trans-Ekulu area, and some parts of Abakpa Nike area (see Ikejiofor, 2006). The Master Plan for Enugu (1979, Phase 2, p. 122) also took note of these distinct settlements, and called them 'traditional villages' or "third settlement type".

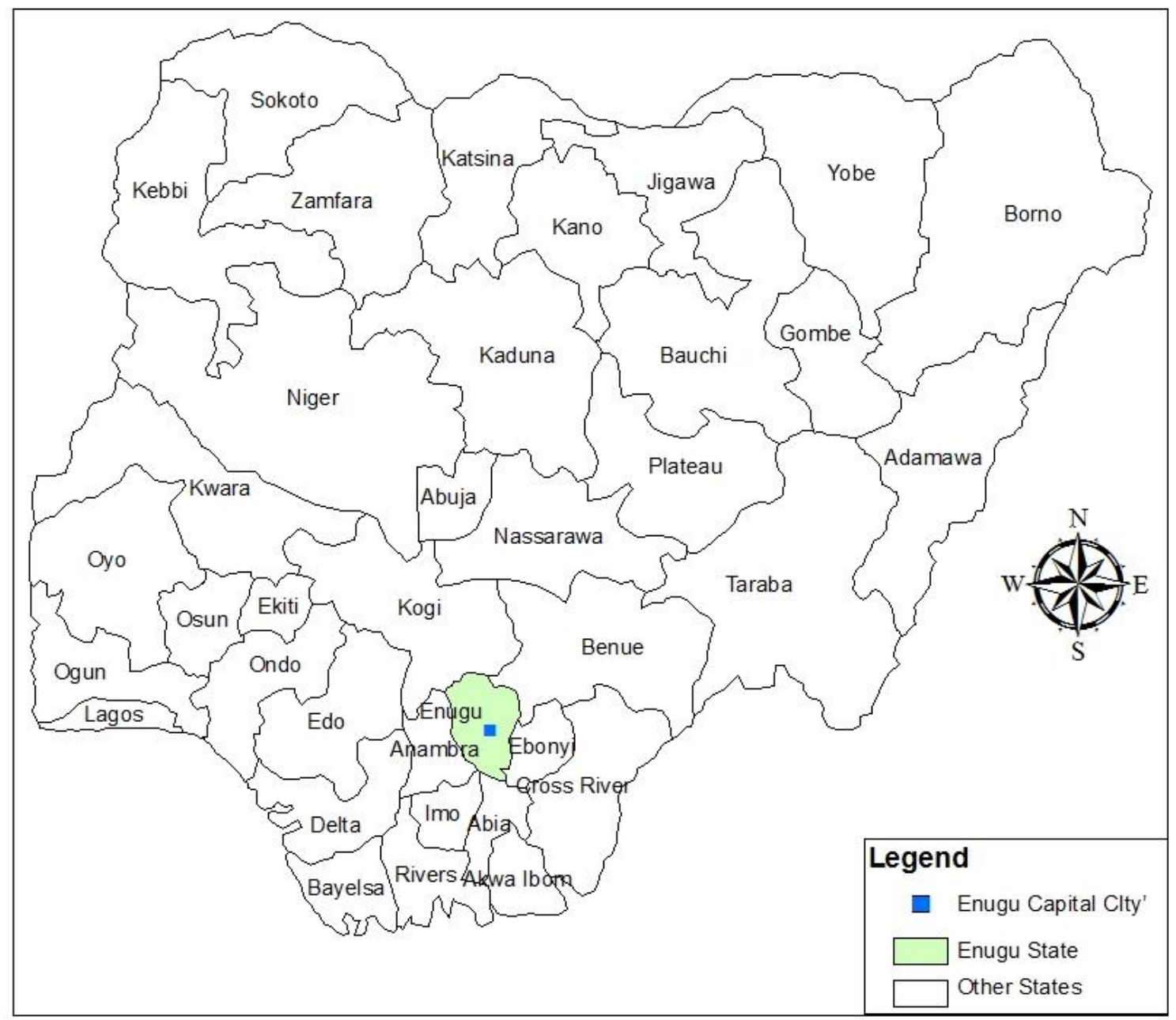

Figure 3. Nigeria showing Enugu State and Enugu Capital City.

Ugbo-Okonkwo community (literal translation: 'Okonkwo's farmstead') was purposively chosen for the study. The controversial nature of the eviction threat coupled with the fact that the community mirrors similar tenure conditions, dilemmas and struggles faced by, or facing, other customary communities around Enugu capital city and further afield also contributed to 
this choice. More so, the study is also useful for a better understanding of land dynamics and ownership challenges in other expanding capital cities in Nigeria.

The community is situated in the north-eastern corner of Enugu capital city, roughly 6 Kilometres from the city centre. The origin is traced to around 1896 when migrant farmers from Affa and Ezeagu villages under the leadership of their forerunner, one Okonkwo, were granted 'settlement land' by the Nike landlords. Tracts of land currently occupied by Enugu capital city are traceable to the indigenous people of Awkunanaw, Akagbe Ugwu, Ngwo, and Nike people. Out of these four kinfolks, the Nike people are known to account for nearly $90 \%$ of the total land delivery (Ikejiofor, 2006, p. 453). Ugbo-Okonkwo has grown largely in a spontaneous manner with an estimated population of 20,000 people (Edike, 2014, February 7). The community appears quite congested with an area of approximately 3.5 hectares split into two roughly equal parts by the two-lane Chime Avenue, and is crisscrossed solely by routeways. It stands in sharp contrast to its contiguous neighbourhood - the high-brow City Layout in the Upper Chime area (Plates 1 and 2). While the typical houses here appear dilapidated and substandard, there are nonetheless incipient building modernisation and improvements ongoing on incremental basis.

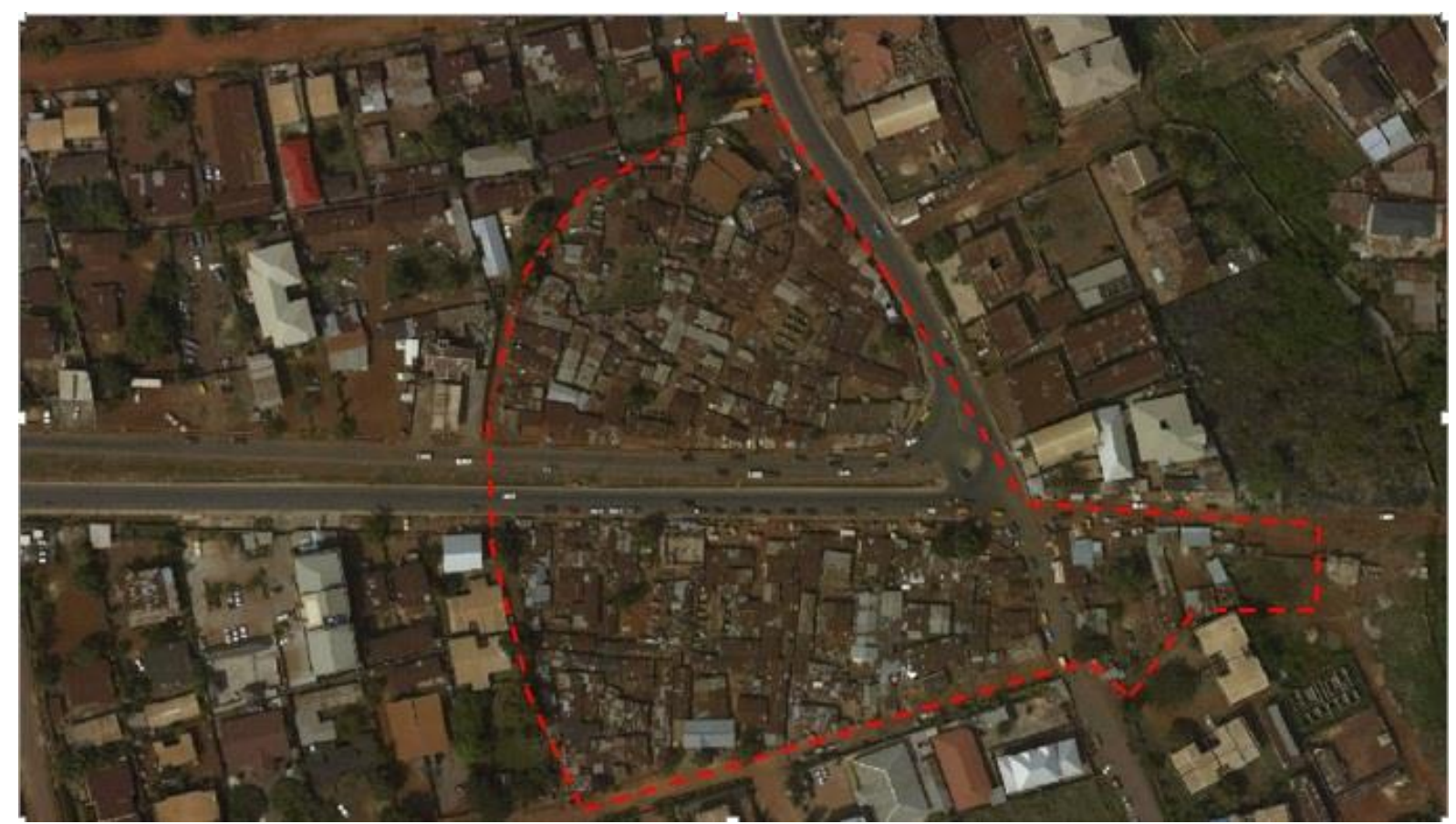

Plate 1.Air photo image of Ugbo Okonkwo (with dotted enclosure) in the City Layout Area of Enugu as at 2015 . 


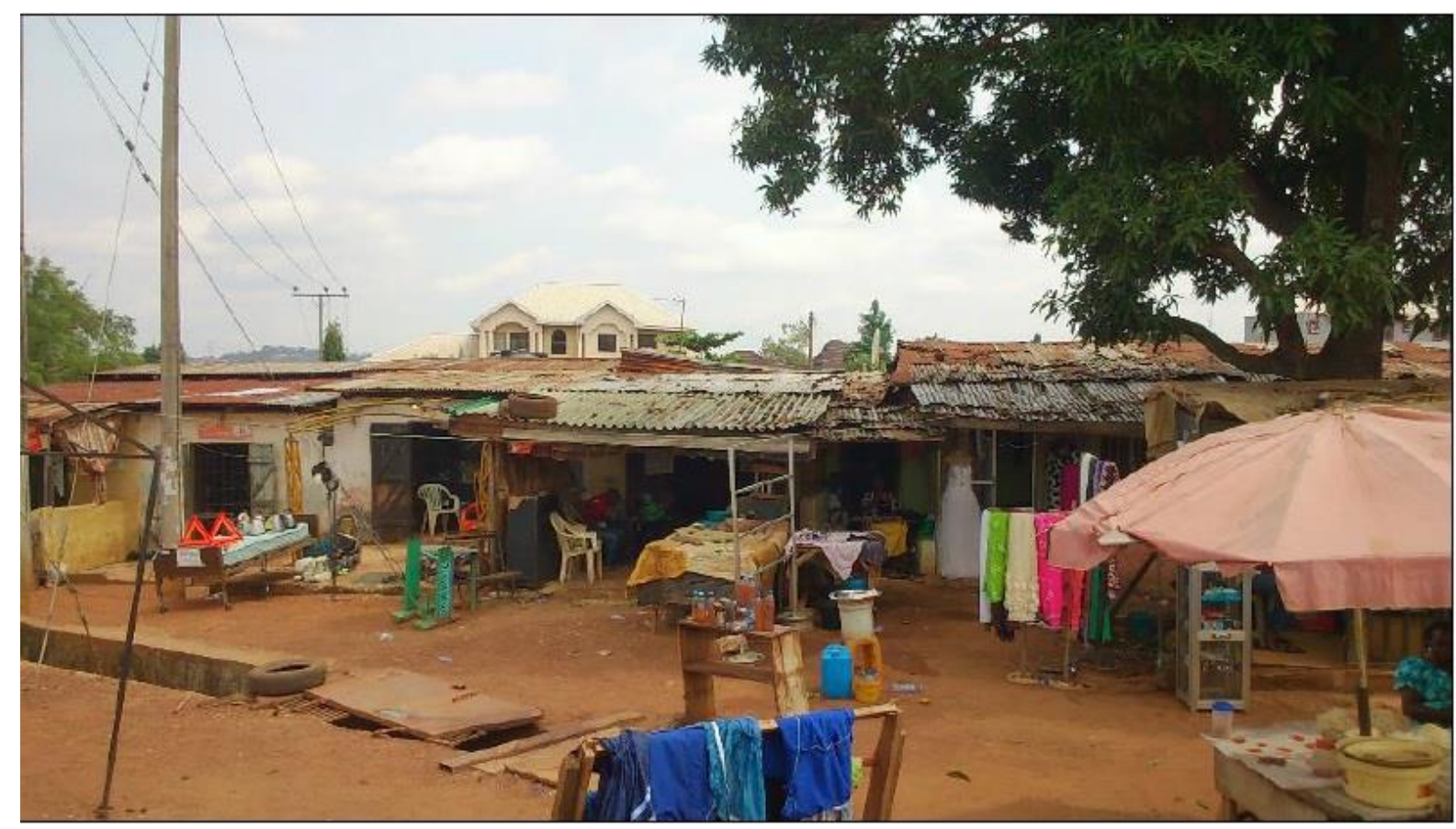

Plate 2. A view of Ugbo Okonkwo from Chime Avenue, Enugu: 'Development met us here'

\subsection{Data Collection and Analysis}

In order to gather required base line data, the study made use of spatial data and analysis (courtesy of Onyebueke and Ndukwu, 2017), desktop research and case study approach.Three analytical maps showing expansion extents of Enugu in 1985, 2000, and 2015 (refer to Figure 4A, B \& C) were analysed based on three satellite images (Landsat 5 Thematic Mapper, Landsat 7 Enhanced Thematic Mapper, and Landsat 8 Operational Land Imager) for equivalent years respectively. Desktop research entailed collection of secondary data concerning case study details and related displacement literature across local, national, and international contexts. Manual search and keyword-based online search (using Google Scholar and Science Direct) provided requisite newspapers, books, journals, and periodicals. Case study method necessitated site observations, document acquisition, and in-depth face-to-face interviews over defined time periods (Leedy \& Ormrod, 2010). An audiotape, camera and field note aided the documentation. Data convergence or triangulation facilitated improved reliability and internal validity, and this was achieved through multiple data sourcing, purposive sampling of 12 respondents/participant selected from all stages of the event as well as repeated checks and observations. Table 2 categorises the event strata from which respondents were selected, viz.: project affected persons (PAPs)/associates, public agency officials/civil society activists/journalists, and traditional authority representative. Hints from local newspapers, for example Edike (2014, February 7), coupled with tips from initial respondents and residents enabled appropriate respondents identification and interviews until saturation point is reached 
regarding emerging insights (snow-ball sampling). Selected respondents voluntarily consented to tape-recorded interviews, which normally held in and around their houses, shops, and offices.

Table 2. The list of selected respondents and relevant details

\begin{tabular}{|c|c|c|c|}
\hline EVENT STRATA & CODE NAMES & DESCRIPTIONS & INTERVIEW DATES \\
\hline \multirow{7}{*}{$\begin{array}{l}\text { Project Affected } \\
\text { People and } \\
\text { Associates }\end{array}$} & Respondent 1 & Shop keeper & $\begin{array}{l}6 \& 13 \text { September, } \\
2016\end{array}$ \\
\hline & Respondent 2 & $\begin{array}{l}\text { Son of a property owner } \\
\text { visiting the family from } \\
\text { Abuja }\end{array}$ & 21 September, 2016 \\
\hline & Respondent 3 & Tenant in Ugbo-Okonkwo & 21 September, 2016 \\
\hline & Respondent 4 & Community Attorney & 15 November, 2016 \\
\hline & Respondent 5 & $\begin{array}{l}\text { Main community } \\
\text { leader/property owner }\end{array}$ & $\begin{array}{l}19 \& 23 \text { November, } \\
2016\end{array}$ \\
\hline & Respondent 6 & $\begin{array}{l}\text { Architect/Researcher, } \\
\text { Department of Architecture, } \\
\text { University of Nigeria, } \\
\text { Enugu Campus. }\end{array}$ & 18 November, 2016 \\
\hline & Respondent 7 & $\begin{array}{l}\text { Community leader/property } \\
\text { owner }\end{array}$ & $\begin{array}{l}\text { 13 September, } 2016 \\
\& 16 \text { November, } \\
2016\end{array}$ \\
\hline \multirow[t]{4}{*}{$\begin{array}{l}\text { Public agency } \\
\text { officials/Civil } \\
\text { Society/Media }\end{array}$} & Respondent 8 & $\begin{array}{l}\text { A top executive at Enugu } \\
\text { Capital Territory } \\
\text { Development Authority }\end{array}$ & 8 August, 2016 \\
\hline & Respondent 9 & $\begin{array}{l}\text { An executive in Town } \\
\text { Planning Department of the } \\
\text { Ministry of Lands and } \\
\text { Urban Development } \\
\text { (MLUD) }\end{array}$ & 24 August, 2016 \\
\hline & Respondent 10 & $\begin{array}{l}\text { Journalist/Media } \\
\text { Association Representative }\end{array}$ & 30 November, 2016 \\
\hline & Respondent 11 & $\begin{array}{l}\text { An officer in National } \\
\text { Human Rights Commission } \\
\text { (South East Zonal Office) }\end{array}$ & 5 December, 2016 \\
\hline $\begin{array}{l}\text { Traditional Authority } \\
\text { Representative (Nike } \\
\text { Kingdom) }\end{array}$ & Respondent 12 & $\begin{array}{l}\text { Palace official at the } \\
\text { Odezuluigbo Nike Palace }\end{array}$ & 5 February, 2017 \\
\hline
\end{tabular}

Source: Researchers' field notes.

In order to analyse and make sense of collected mixed data outlays, we resorted to the sequential and multi-layered analysis prescribed by Creswell and Creswell (2017). The four steps were: (i) data organisation and cataloguing vis-à-vis types and sources; (ii) reflecting on the discrete and overall thematic meaning; (iii) codification and interpretation of emerging facts; and (iv) thematisation and description of the narrative(s). These progressed in tandem with other core procedures such as manual transcriptions of the interviews from audios to texts; 
sorting and selecting appropriate photographs and visual materials; and chronicling of the event episodes relative to the date of removal notice (Friday, January 30, 2014). For instance, inscriptions on the protest placards and the entire transcript texts were thematically analysed and triangulated in order to obtain the affective and discursive stories of key stakeholders and PAPs. Finally, the case narrative was constructed and written up.

\section{Results and Discussion}

The results are discussed in a narrative form themes emerging from the event scenarios. The section is organised as follows: spatio-temporal dynamics of urban encroachment; conflicts of authorities, laws, 'schemes' and vistas; customary 'rightsholders' and intrigues of city upgrading and shadow bailiffs; resistance strategies and the halted eviction; and lessons of experience and emerging issues.

\subsection{Spatio-temporal Dynamics of Urban Encroachment}

Displacement rumours started on Friday of January 30, 2014 when the Enugu Capital Territory Development Authority (ECTDA) - a planning agency of the Enugu State government - served eviction notices to Ugbo-Okonkwo community for alleged non-compliance with Enugu master plan. Yet, its formal recognition as 'Ugbo-Okonkwo Electoral Ward 10' with two polling units (Enugu State Government, 2012, p. 225) and status as a customary community appear to say otherwise, signifying yet another obverse instance of interpenetration of urban laws. An eerie sense of apprehension and uncertainty then descended on this once-idyllic community, though everything was to become quite scurried in the week following the eviction order. Determined to stay put, community people (land or property owners and tenants) hastily strategised their next moves before the specified deadline of Thursday, February 7, 2014 in order to avert the looming threat. They had to prepare for other eventualities, if time ran out on them. Table 3 presents the outline of the events plot, key stakeholders' roles in addition to event pattern and sequence of the key stakeholders.

Over time, Ugbo-Okonkwo had become a very reticent community that is quite wary of strangers. We observed this throughout our visits, and in particular, in the unprompted confrontation by Respondent 2, a man in mid-thirties, while trying to interview a few disinclined residents. He quietly cautioned us to speak first to the community leader in order to obtain his permission. Although he was raised in the community, he had relocated to Abuja 
a few years ago, from where he was now visiting his aged landowner-father, who had taken ill the week before.

Table 3. Events plot and key stakeholders in the halted eviction at Ugbo Okonkwo, Enugu.

\begin{tabular}{|c|c|c|}
\hline DATE & EVENT & $\begin{array}{l}\text { ACTORS/ } \\
\text { STAKEHOLDERS }\end{array}$ \\
\hline $\begin{array}{l}\text { Friday, January } \\
30,2014\end{array}$ & $\begin{array}{l}\text { Ugbo-Okonkwo community served removal } \\
\text { notices by ECTDA. Similar removal notices } \\
\text { were also served in four other 'slums' in } \\
\text { Enugu, namely: Ugbo Chime, Obiagu, Ikilike } \\
\text { and Iva Valley. }\end{array}$ & $\begin{array}{l}\text { ECTDA workers, community } \\
\text { residents (property owners } \\
\text { and tenants) }\end{array}$ \\
\hline $\begin{array}{l}\text { Saturday } \\
\text { February } 1,2014\end{array}$ & $\begin{array}{l}\text { Ugbo-Okonkwo community had series of } \\
\text { meetings and consultations, including } \\
\text { decisions to hire an attorney and make } \\
\text { representations to Odezuluigbo Nike Palace to } \\
\text { seek solidarity and support. The Nike people } \\
\text { are the original allotters of the land in } \\
\text { question. }\end{array}$ & Community representatives, \\
\hline $\begin{array}{l}\text { Monday, } \\
\text { February 3, } 2014\end{array}$ & $\begin{array}{l}\text { The community attorney filed a motion for an } \\
\text { interim injunction to restrain ECTDA and the } \\
\text { administration from proceeding with the } \\
\text { threatened eviction. }\end{array}$ & $\begin{array}{l}\text { Community attorney, } \\
\text { Community representatives }\end{array}$ \\
\hline \multirow[t]{3}{*}{$\begin{array}{l}\text { Tuesday } \\
\text { February 4, } 2014\end{array}$} & $\begin{array}{l}\text { Impromptu visit to Ugbo Okonkwo by the } \\
\text { General Manager of ECTDA in the company } \\
\text { of two management staff members. }\end{array}$ & $\begin{array}{l}\text { ECTDA General Manager } \\
\text { and management staff, Ugbo } \\
\text { Okonkwo property owners } \\
\text { and tenants, the press, and the } \\
\text { curious public }\end{array}$ \\
\hline & \multirow{2}{*}{$\begin{array}{l}\text { An impromptu dialogue between the ECTDA } \\
\text { team and property owner's representative and } \\
\text { sympathisers (Priest in-charge, Our Lady of } \\
\text { Perpetual Help Catholic church, New Haven) } \\
\text { ensued. }\end{array}$} & Same as above \\
\hline & & Same as above \\
\hline $\begin{array}{l}\text { Wednesday } \\
\text { February 5, } 2014\end{array}$ & $\begin{array}{l}\text { Interim injunction Suit No. E/32M/2014 } \\
\text { granted by Justice A. R. Ozoemena of the } \\
\text { Enugu State High Court. }\end{array}$ & $\begin{array}{l}\text { High Court Judge, court } \\
\text { bailiffs }\end{array}$ \\
\hline $\begin{array}{l}\text { Friday, February } \\
7,2014\end{array}$ & $\begin{array}{l}\text { Mobilisation, prayers for divine intervention } \\
\text { and protest march by Ugbo-Okonkwo } \\
\text { residents through the major streets leading to } \\
\text { the Enugu State Government House }\end{array}$ & $\begin{array}{l}\text { Property owners and tenants, } \\
\text { the press, curious public }\end{array}$ \\
\hline $\begin{array}{l}\text { February 12, } \\
2014\end{array}$ & $\begin{array}{l}\text { Notice of hearing issued by the Judge of } \\
\text { Enugu State High Court. }\end{array}$ & $\begin{array}{l}\text { Apparently the final stoke to } \\
\text { the ECTDA eviction. }\end{array}$ \\
\hline $\begin{array}{l}\text { From February } \\
13,2014\end{array}$ & $\begin{array}{l}\text { Tension and conflict begin to die down } \\
\text { progressively in Ugbo-Okonkwo community }\end{array}$ & \\
\hline
\end{tabular}

Sources: Newspaper publications [Edike (2014, February 7), Peters \& Arum (2014, March 13), supplemented by key informant interviews. 
Eventually, we had to obtain some kind of verbal permission (a phone call to introduce us) from the community attorney (Respondent 4) before the two main community leaders (Respondents 5 and 7) finally agreed to talk to us. To address the initial facet of our first objective, we visualise the urban encroachment scenario at Ugbo-Okonkwo community by showing the spatio-temporal expansions of Enugu and its incursion into adjoining territories over time (Figures 4 A, B \& C).

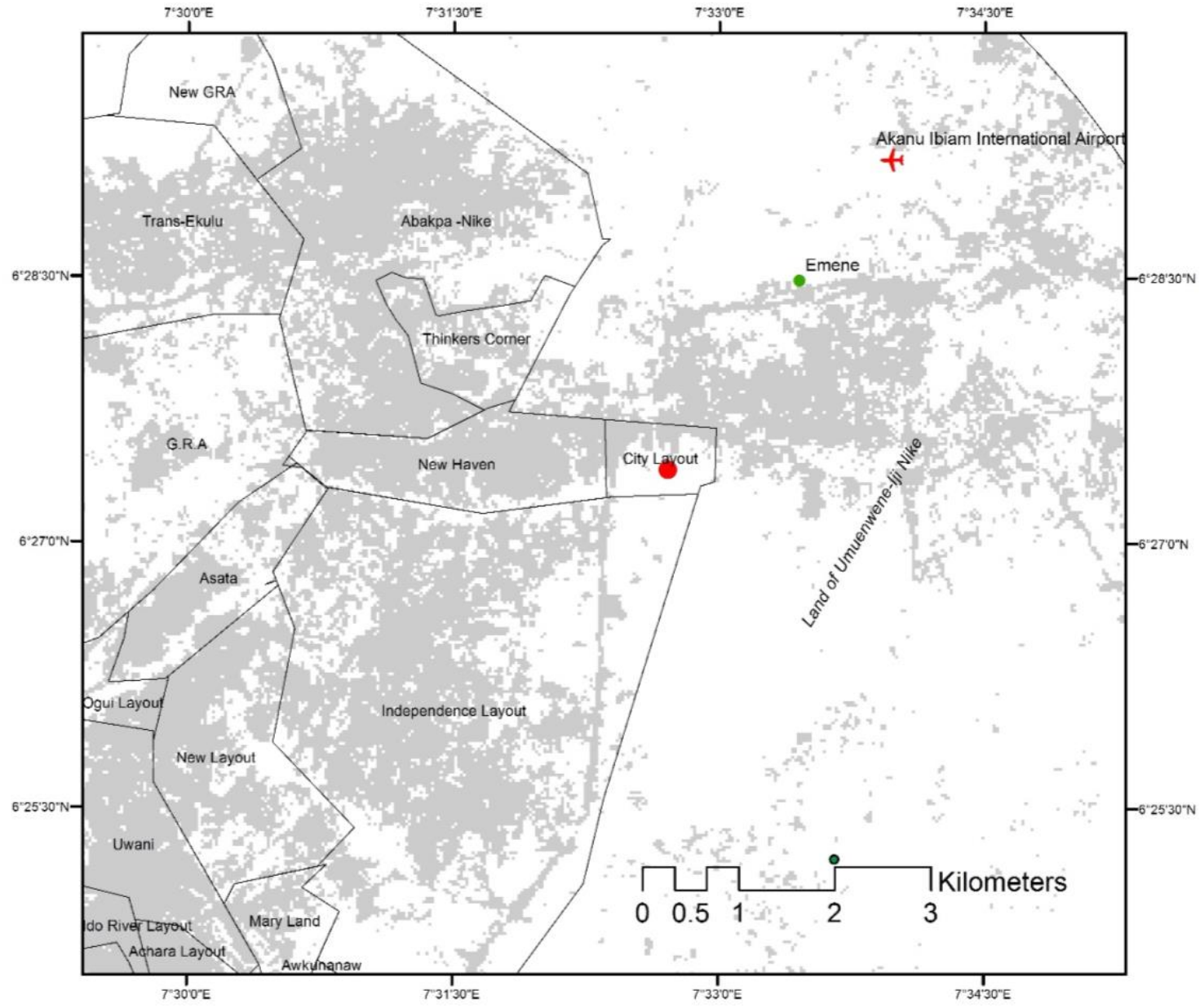

- A. Urban extent in the year 1985 


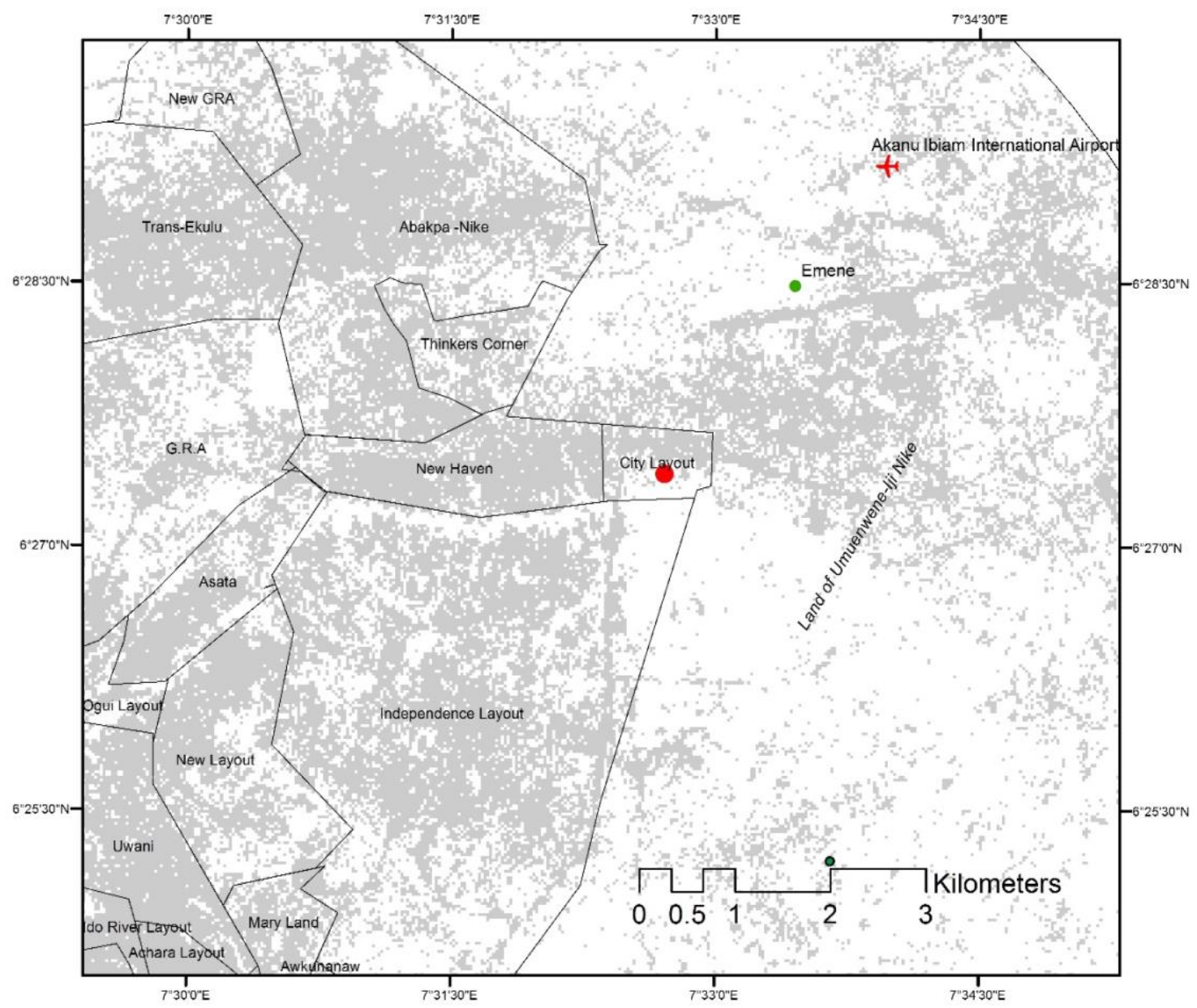

B. Urban extent in the year 2000 


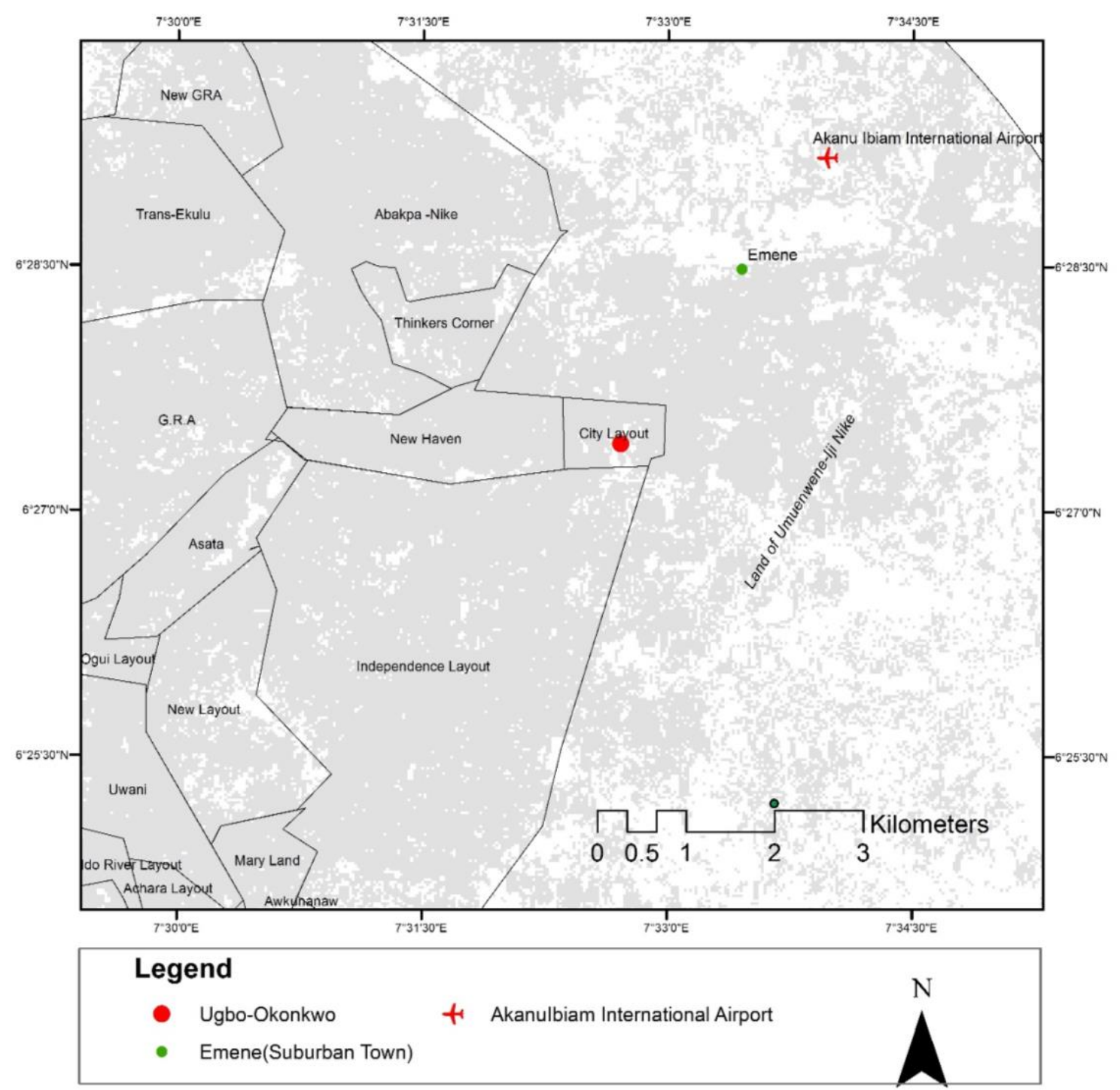

- C. Urban extent in the year 2015

Figure 4. Situation of Ugbo-Okonkwo relative to expanding urban boundaries of Enugu Capital City, Enugu State of Nigeria in 1985, 2000, and 2015.

Affective and discursive feedback from community members - for example, this aphorism 'development met us here' - tend to connote the tentative encroachment pressures (incursions from government and real estate), and answer the second facet of objective one as we shall see from succeeding dialogue. Respondent 5, a man in his late 50s, is a top civil servant in Enugu State, and a direct descendant of the patriarchal Okonkwo. He insists that Ugbo-Okonkwo property owners prefer not to toy with their "“ancestral heritage', rightfully acquired from the bona fide land owners [Nike people]", despite several lures and coercions to push them out. In his own words: 
"There is no need going outside the city (i.e., going somewhere else). God has given us here. Is that because, we have been staying centuries ago and development came here and then you push us away; is it Godly, is it wise? [Julian: I don't think so]. Fine, fine, fine, fine [All: laughs]. It's not when you see development which everyone is praying for, when it comes to you then you run again inside the bush again; at a point in time you become an animal in the bush, you see. [...] That is it and there is joy in developing what you have. There is joy in developing what you have - a total legacy for us."

In pithy reminiscences of urban encroachment that buttresses imminent loss of cultural property (see Wiersma, 2004; Morrison, 2017), another community leader (Respondent 7), and first cousin to Respondent 5, corroborated this claim to autochthonous occupation:

"Our major regrets and annoyance emanate from the fact that we have lived here, development met us here [...] because when we came here, we [or rather] our forefathers created the paths to this place. So, as we settled here, many other people started coming closer. Our fore-fathers met and chased away so many tigers here."

As a response to the second objective, we explore customary-statutory tenure conflicts, the prevailing politics and power relations in land expropriations as well as the inherent tactics and resistances in succeeding subsections.

\subsection{Conflicts of Authorities, Laws, 'Schemes', and Vistas}

The historical land concession to Ugbo-Okonkwo ancestors by Nike people or traditional authority is well-known, and represents a typical case of customary tenancy. In fact, entire land tracts that constitute New Haven neighbourhood, including City Layouts - the high peripheral income neighbourhood that is virtually engulfing this customary community - were all specifically transferred from Umuenwene-Iji Nike Village, one of the numerous villages in the Nike Kingdom (Respondents 1, 3, 5, 6, 7 \& 12). Respondent 12 is an official at the Odezuluigbo (Nike) Palace, and he explicitly confirmed the support of the Odezuluigbo III of Nike Kingdom, Igwe Julius Nnaji, during the trying period of January 30, 2014. He affirmed that:

"The status of Ugbo-Okonkwo residents was not in doubt just like other Ugbos or farm settlements around Enugu, The community is mostly made of our 'customary tenants' from Ezeagu; and as far as I can tell most of them have actualised or perfected their title deeds. During their travail with ECTDA (Enugu Capital Territory Development Authority), I believe we made a case for them although I cannot lay my hands on written document to that effect right now."

He blamed the eviction attempt on 'over-ambitious activities' of those he called 'usurpers' with questionable interests in community lands. Incidentally, one executive in the Town Planning 
Department of the Ministry of Lands and Urban Development (MLUD) (Respondent 9), who is acquainted with the Ugbo-Okonkwo tenancy pact, also corroborated the story:

\begin{abstract}
"I want to point out that Ugbo-Okonkwo is not within government acquired area. Government never acquired the place for any reason. Rather, Ugbo-Okonkwo is within a layout, a scheme approved by government for Umuenwene-Iji Nike village who are the original owners of the land. We call that layout City Layout. So, UgboOkonkwo is within City Layout; and by provision of the scheme, the original residents of ...eh, at Ugbo-Okonkwo were farmers from Ezeagu. They entered into agreement with the community to lease out some portions of land for farming purposes. [...] They occupied the place as farmers, tenant farmers when the scheme was framed and approved for Umuenwene-Iji Nike. In their own wisdom, I am talking about sponsors of the scheme; they decided not to sack them from that particular portion they occupied ab initio. Rather, they said, continue to live there, at any point in time we need our land, we take it from you unless you are now prepared to pay for the value of plots on which you are now farming. You understand?"
\end{abstract}

He emphasised that "our ministry (MLUD) is solely in charge of all land matters; all instruments of land - giving approval for master plans, planning schemes, enforcing planning provisions in such approved schemes and plans". However, what was left unsaid is that the continuous outward expansion of Enugu is both engulfing and overlapping with customary tenure laws, authorities, 'schemes', and values/vistas, thereby creating multiple interfaces of conflicts (Dadashpoor \& Somayeh, 2019). Such conflicts of interests, which are often underlined by unequal power relations and clashes in legal/normative values, are occasioned by divergences between the customary practices (based on tenets of unwritten tenancy codes, 'farm settlement' arrangements, and traditional support system) and statutory tenure/urban law practices (LUA-1978 and formal layout schemes). Failure to properly distinguish and perhaps reconcile these diverse 'planning forms' is clearly manifest in aspects of the Ugbo-Okonkwo episode. Apart from tagging the settlement a 'slum' or 'third settlement type' (see Plates 1 and 2), ECTDA eviction threat and apparent reluctance of MLUD to register plots and approve building plans in the community further elaborate these contradictions. Since urban planning in Nigeria is rarely receptive of alternative planning forms, suspicion and tensions often persist between government planning agencies, traditional authorities, and community-based/nongovernmental organisations (Lamond et al, 2015).

\title{
4.3 Customary 'Rightsholders' and Intrigues of City Upgrading and Shadow Bailiffs
}

Perhaps as intended, the widely reported manoeuvres by ECTDA exacerbated the already tense situation. Stationing of a bulldozer adjacent to Ugbo-Okonkwo and the impromptu visit and 
public address by the ECTDA Managing Director on the morning of Tuesday, February 4, 2014 appear to be part of this orchestration (Edike, 2014, February 7). To the spontaneous crowd of property owners, tenants, sympathisers, and bystanders that had gathered, he resolutely proclaimed that "the government of Chime (Mr Sullivan Chime, the Executive Governor of Enugu State between 2007 and 2015) does not want to see any slum in the city and, therefore, has instructed me to carry out the exercise" (Edike, 2014, February 7). In response, one community leader (Respondent 5), who had sauntered from across the road with crutches, implored government for more time or 'grace period' to improve their housing standards, stressing that:

"...it will be a sin against God and man if they should throw out the poor people of Ugbo-Okonkwo community of about 20,000 people, including women and children, whose livelihood solely depends on these houses" (Edike, 2014, February 7).

It was also reported that a Catholic priest from nearby Our Lady of Perpetual Help Catholic Church in the nearby New Haven was also at hand to plead for the community, which equally houses some of his parishioners. The empathetic clergyman entreated the ECTDA boss:

"These people are members of my congregation. I came to plead on their behalf. They told me about their plight...Please I am only pleading that you should listen to their cries and please avoid doing the things that may end up separating the spirit from the body. I am concerned by what will happen to my congregation. Government should please consider the poverty level of the people of Ugbo-Okonkwo and give them more time to rebuild their houses" (Edike, 2014, February 7).

The official visit of the ECTDA Managing Director was quite brief and soon came to an end, providing neither clear answers nor clarifications. Even the mandatory 21 days quit notice prescribed in Sections 53-56 of the Nigerian Urban and Regional Planning Act of 1992 was not even observed.

The general impression in Ugbo-Okonkwo was that government actions were targeted at instigating housing/urban regeneration in their community. This opinion is not surprising considering the city beautification project that commenced in the First Quarter of 2007 by the Governor Sullivan Chime administration. Based on this, one of the community leaders, Respondent 7 had remarked:

"When they wanted to upgrade this place, we expected that they would approach us with an approved plan for the upgrade and a timeline for achieving that... or they would tell us that they want to build for us and agree on a repayment plan; or 
anybody who can afford to build should go ahead and do so. They never told us anything or consulted us. All we saw was that one day they came with bulldozer to demolish this place. We were very much annoyed by this action and we wondered whether we voted in that government to come and destroy us and evict us. We were saddened by that. Some of us who have the wherewithal to approve their plots have started. If they had told us earlier, we would all have cooperated because good things beget good things."

Apparently, the 'custodians' of Ugbo-Okonkwo are not opposed to upgrading their community, but the main grouse seems to be that ECTDA neither followed due process nor invited them to any discussion. In the words of Respondent 5:

"How I would have loved the government to approach the issue? [Repeating the question for clarity sake]. Had it been they came, gave us time, told us, already they have told us they want specification; the issue is that the people that came did not even have respect for us here. They came like lions in the forest-predators in search of a prey. So, the communities were not happy the way they came. They did not even consult anybody, they just dumped a letter, gave us 7 days. Here in Nigeria? Politicians gave 7 days here in Nigeria ... and our brother whom we know? [...] So, and they knew it all, they were doing it for themselves. So, after due consultation we use to follow it legally. That's why we were able to..."

He stopped short of completing the sentence, certain that the Enugu High Court order, based on the interim injunction filed by the community attorney (Respondent 4), was now common knowledge. The Enugu High Court had in the Suit No. E/32M/2014 of Wednesday February 5, 2014 issued by Justice A. R. Ozoemena ordered ECTDA, the State Attorney General, and their agents, privies or assigns from carrying out the threatened eviction "pending hearing and determination of the motion on notice". The motion for hearing and substantive determination of the case was fixed for $12^{\text {th }}$ February, 2014. This high court demand mandate could not have come at a better time, and in fact, appears in retrospect to qualify as a landmark decision.

Respondent 4 is an official of the National Human Rights Commission (NHRC), South-East Zonal Office (Respondent 11) and a female lawyer. Being conversant with the Ugbo-Okonkwo case, she thought that it fit into some of those actions of administrative unlawful with questionable human right implications. According to her:

"Unlawful eviction of citizens from their shelters has been a serious problem to National Human Rights Commission as it borders on their right to shelter. Our studies have revealed that after food, the next important thing to man is shelter; because no matter how well you have fed and you have no place of abode, you expose 
yourself to all forms of natural and unnatural vagrancies. You are a prey to anything."

Some curious caginess pervaded the entire case. It not only kept affected residents in the dark about intended project rationales, but somehow it never occurred to them to consult or petition NHRC. Inter-agency cooperation also suffered in the process. Despite the statutory planning oversight function MLUD exercises within Enugu capital city and beyond, the ministry never received any official notification to that effect (Respondent 9). Choosing his words carefully, he remarked that their exclusion from an anticipated intervention of that magnitude was a grave 'oversight' or 'misstep' on the part of ECTDA. To him, "government works (or should work) as a unit":

"The ECTDA, like you know, is a recent creation. And the essence, to the best of my knowledge, is to harmonise approval within Enugu Capital Territory so that what happens at Enugu East (LGA) is the same thing that happens at Enugu South (LGA); Right? By ensuring that only one person gives final approval. [...] to make sure that Enugu is functional. And for you to live a slum within a beautiful area like City Layout, I mean, could be worrisome. But, from the social point of view, it will be wrong to eject the people because they had an agreement with the original land owners. The original land owners had not started worrying them to vacate."

Could ECTDA have defied due process and planning ethics to unilaterally initiate the said project? Or was it a desperate last-ditch directive by the state governor (Mr Sullivan Chime), who had barely one year to the end his tenure, to recover contested lands before leaving office? Or was ECTDA merely acting, like certain informants seem to suggest, as a protégé of powerful contestants trying to swoop on vulnerable community land?

Although a veil of silence is still maintained over who could be the actual mastermind of the botched eviction, some whispers making rounds appear to point accusing fingers at benefactors of certain prominent land broker (now deceased), who was at some point the community lawyer for Nike people (Respondents 4, 7, 12). It is an age-long custom of Nike Kingdom and other land-owning communities to remunerate professional services rendered to them with plots of land. And so, there are speculations that the family in question might have been trying to resuscitate a certain unproven claims to a partial or complete swath of Ugbo-Okonkwo land (Respondent 12). If that is the case, ECTDA might have deigned to act as a 'shadow bailiff' for the family estate. Respondent 4 (community attorney) asserted that he picked up such hints during preliminary court proceedings: 
"But later, when they now found out that the court said: 'No, you cannot do it'. ... if you do it, there must be reason. But, they had no reason. That that place is ghetto is unheard of. See what happened, when they were replying to our statement of claim, what they said was that their clients are the owners of that place, that it is [name withheld].... That the place belongs to [name withheld], which means they are fighting for somebody, may be, the person must have said, get this place for me and you will take this. But, thank God for the court, they said no, it cannot happen now. Tell us why you must do it, and that is where we are now."

However, neither the benefactor's family nor their defence lawyers could be reached to confirm this allegation. This ensuing intrigue is arguably a natural outcome of legal and planning systems that are devoid of a transparent and participatory process and therefore prone to abuse (Lamond et al., 2015; Tagliarino et al. 2018). Given the current scope of this research and available space, what is most important at this juncture is to ascertain the community-led responses invoked by this eviction threat.

\subsection{Resistance Strategies and the Halted Eviction}

In the Foucauldian sense, exercise of overbearing power is often met by active resistance. Protests and struggles of Ugbo-Okonkwo residents epitomise this condition in more ways than one. As already outlined in the plot (refer also to Table 3), community strategies deployed to resist the threatened ECTDA eviction include: mobilisation (internal and media), meetings, decisions, prayers for divine intervention, including consultations, appeals/representations, legal action as well as public protests. Although explicitly intended to arouse public sympathy and support for their cause, these resistance strategies (both passive and active) were intended to have either specific or broad-spectrum effects on diverse publics and powers (Table 4 and Table 5). Such appeals that hinge on own vulnerability and moral conscience underlie most of the afore-mentioned resistance and redress-seeking strategies as various informative captions hand-written on placards clearly show (Plate 3). Everyday resistance practices or people-led movements signify spontaneous reactions by threatened groups to remain and/or prevent uncompensated displacements (Onyebueke et al., 2019; Martiniello, 2019). Invariably, such movements contribute to further deepening recognition or tolerance for customary tenure in affected cities.

Ugbo-Okonkwo residents' battle to stay put was fought at different levels. Apart from alreadyenumerated everyday resistances, dialectical dissensions also came to the fore. Dialectical contests are normally fought over toponymic or place-name labelling. Physical characteristics, notwithstanding, involved residents often opt for identity-inspiring place while government and planning agencies often choose 'disparaging metaphors' that tend to 'demonise' such 
settlements (Cabannes et al., 2010, p. 12; Morrison, 2017, p. 34). Typically, Ugbo-Okonkwo property owners and sympathisers were insistent on identifying Ugbo-Okonkwo as a 'community' rather than a 'slum' or 'ghetto' or even 'third settlement type' (Respondents 4, 5, 6, 7, 11 and 12). Respondent 4 is one of the tenants who had played active role throughout the whole episode. Respondent 6, on the other hand, is an architect/researcher in the Department of Architecture of University of Nigeria, Enugu Campus, who had worked on a slum improvement project in Ugbo-Okonkwo between 2004 and 2005 (see Chineme, Ifenancho, Kurth, \& Zellweger, 2005).

Table 4. Key resistance strategies, the intended purpose and target publics

\begin{tabular}{|c|c|c|}
\hline $\begin{array}{l}\text { KEY RESISTANCE } \\
\text { STRATEGIES }\end{array}$ & $\begin{array}{l}\text { INTENDED PURPOSE AND } \\
\text { PUBLICS/POWERS }\end{array}$ & $\begin{array}{l}\text { POSSIBLE EFFECTS ON } \\
\text { TENURE PRACTICE AND } \\
\text { LAND USE }\end{array}$ \\
\hline \multicolumn{3}{|c|}{ Passive Resistance } \\
\hline $\begin{array}{l}\text { Civil disobedience or } \\
\text { refusal to comply with the } \\
\text { ECTDA } \\
\text { eviction/demolition order. }\end{array}$ & $\begin{array}{l}\text { Protect their customary proprietary } \\
\text { rights against ECTDA's } \\
\text { compulsory acquisition bid. }\end{array}$ & $\begin{array}{l}\text { Can bolster customary tenure and } \\
\text { community livelihoods/ culture. } \\
\text { Potentials to impede land } \\
\text { expropriation, depleted supply of } \\
\text { building land, and boost 'frog- } \\
\text { leaping'. }\end{array}$ \\
\hline $\begin{array}{l}\text { Mobilisations/meetings, } \\
\text { collective decisions, } \\
\text { consultations, and } \\
\text { alliances. }\end{array}$ & $\begin{array}{l}\text { Galvanising community solidarity } \\
\text { and conscientising the diverse } \\
\text { publics in order to counter the } \\
\text { divisive ploy of the agency and fend } \\
\text { off the eviction threat. }\end{array}$ & $\begin{array}{l}\text { Mobilisation and solidarity are at } \\
\text { the heart of the struggle against } \\
\text { land eviction. }\end{array}$ \\
\hline $\begin{array}{l}\text { Public prayers to God as } \\
\text { well as entreaties to Ana, } \\
\text { the land deity (Dike, 1983; } \\
\text { Edike, 2014). }\end{array}$ & For divine intervention. & $\begin{array}{l}\text { Signifies both loss of faith in the } \\
\text { system and belief in the } \\
\text { supernatural assistance to avert } \\
\text { the threat of displacement. }\end{array}$ \\
\hline $\begin{array}{l}\text { Greater resolve to perfect } \\
\text { their land/property } \\
\text { registration with Ministry } \\
\text { of Lands and Urban } \\
\text { Development (MLUD). } \\
\end{array}$ & $\begin{array}{l}\text { To forestall future eviction threats } \\
\text { from both public and private } \\
\text { agencies. }\end{array}$ & $\begin{array}{l}\text { Formalisation or legal } \\
\text { empowerment through land } \\
\text { registration, and bridging the } \\
\text { customary-statutory tenure } \\
\text { divide. }\end{array}$ \\
\hline \multicolumn{3}{|c|}{ Active Resistance } \\
\hline $\begin{array}{l}\text { Community-initiated legal } \\
\text { action (court injunction) } \\
\text { against ECTDA and } \\
\text { government. }\end{array}$ & $\begin{array}{l}\text { To lawfully block and vacate the } \\
\text { eviction/demolition order, and in } \\
\text { due course, guarantee their } \\
\text { proprietary rights. }\end{array}$ & $\begin{array}{l}\text { Seeking legal remedies through } \\
\text { invoking customary tenurial } \\
\text { rights and other privileges in } \\
\text { common law. }\end{array}$ \\
\hline Media mobilisation & $\begin{array}{l}\text { Making their voices heard. } \\
\text { Publicity towards creating } \\
\text { awareness and public } \\
\text { sympathy/support among the } \\
\text { reading and viewing public. }\end{array}$ & $\begin{array}{l}\text { Publicity to create awareness and } \\
\text { sway public opinion towards } \\
\text { obtaining a stay order. }\end{array}$ \\
\hline $\begin{array}{l}\text { Street or public protests } \\
\text { march by property owners } \\
\text { and residents }\end{array}$ & $\begin{array}{l}\text { Publicity to create awareness and } \\
\text { public sympathy/support, } \\
\text { particularly among the grassroots. }\end{array}$ & $\begin{array}{l}\text { Prospects of averting the eviction } \\
\text { and restore the status quo ante. } \\
\text { Can bolster customary tenure and } \\
\text { community livelihoods/culture. }\end{array}$ \\
\hline
\end{tabular}

Source: Authors' analysis from miscellaneous sources. 
Table 5. Analysis of inscriptions on protest placards of Ugbo-Okonkwo demonstrators

\begin{tabular}{|c|c|}
\hline PLACARD MESSAGES & INTENDED PUBLICS/POWERS \\
\hline $\begin{array}{l}\text { - "The Lord is my Shepherd" } \\
\text { - "Rev. Fr. Clement Okonkwo pray for } \\
\text { Ugbo-Okonkwo men" }\end{array}$ & God and church authorities \\
\hline $\begin{array}{l}\text { - "No slum in Ugbo-Okonkwo, we } \\
\text { acquired our land legitimately" } \\
\text { - "No government has told us that we live } \\
\text { in a slum" } \\
\text { - "We are law-abiding citizens, we } \\
\text { deserve a home" } \\
\text { - "Your Excellency, we like the good } \\
\text { work you are doing in Enugu State, help } \\
\text { us by stopping this demolition, give us } \\
\text { time to develop our land" } \\
\text { - "We have our title documents, we are } \\
\text { not illegal occupants" } \\
\text { "It is inhuman to evict us from a land } \\
\text { we have occupied for over } 100 \text { years" }\end{array}$ & $\begin{array}{l}\text { ECTDA, Enugu Sate Government, and the } \\
\text { general public. }\end{array}$ \\
\hline $\begin{array}{l}\text { - "It is inhuman to evict us from the land } \\
\text { we have occupied for over } 100 \text { years" } \\
\text { "Royal Highness Igwe S.A Nnaji, } \\
\text { Odezulu-Igbo help your subjects in } \\
\text { Ugbo Okonkwo". }\end{array}$ & $\begin{array}{l}\text { Igwe Nike, traditional authorities, and the } \\
\text { general public. }\end{array}$ \\
\hline
\end{tabular}

Sources: Edike (2014, February 7); Peters \& Arum (2014, March 13); and Authors' reading of published photographs.

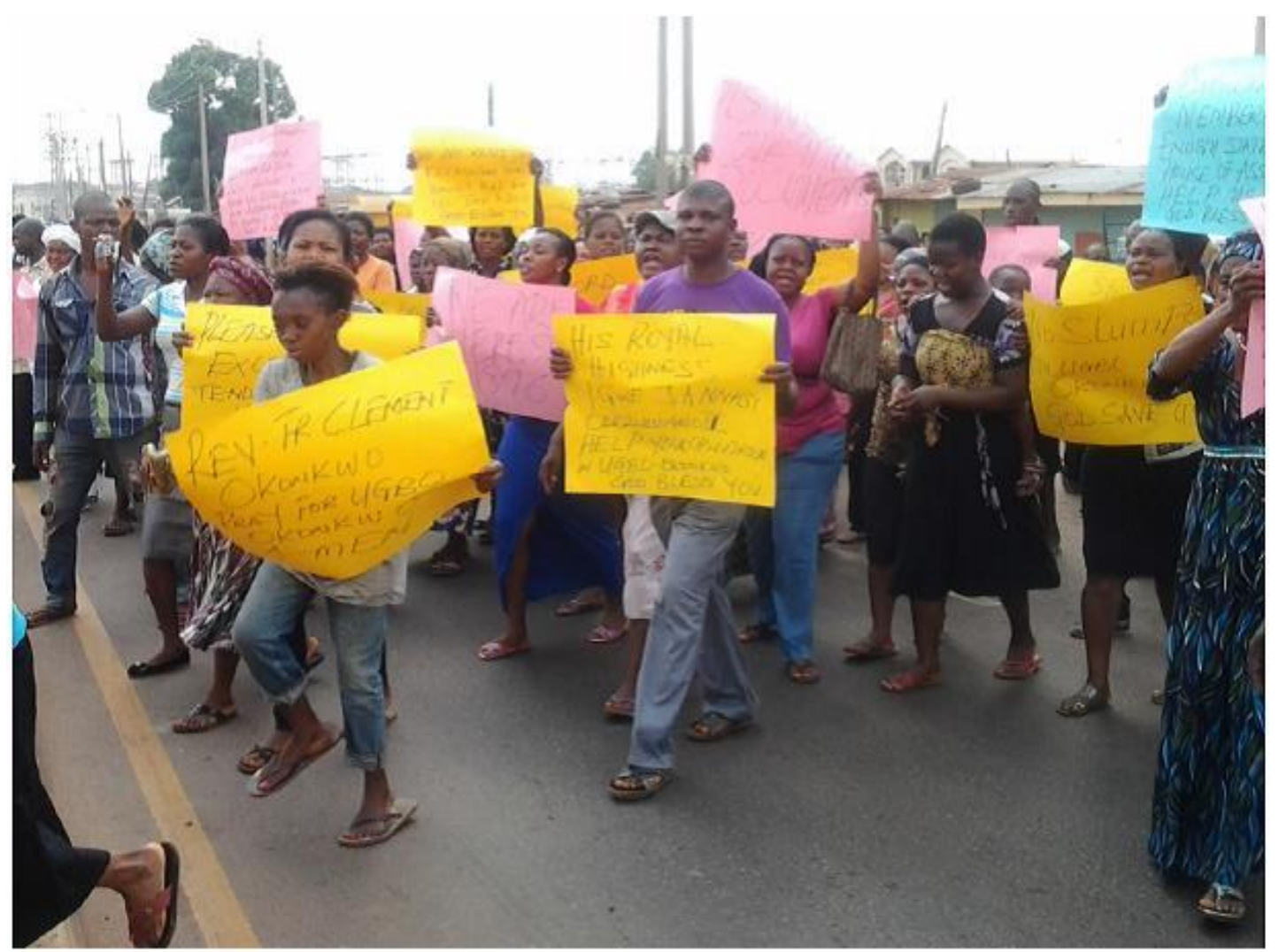

Plate 3. Street protests by placard-wielding Ugbo Okonkwo demonstrators Friday, February 7, 2014 (The Advocate). 
According to Respondent 5:

"Look at the structures they complained about (gesturing for us to see), for you to get me right. They complained that there is no good structures. We told them to give us time. That is why I told you, they did not come [...] they came through the back door, they were not honest. They told us we have ... what did they call it? ... 'slums' here, but I said no, it is not a 'slum'! I know where 'slums' can be found. Take our plan, approve it for us, give your structure how to develop our place and give us time equally; and some have started you can have a picture ... look at another one that is ongoing. Do you think someone can come tomorrow and tell us we are going to vacate?"

The community attorney corroborated this viewpoint by referring to community's deep customary and historical roots:

"These people, they lived there for hundreds of years. Their grandfather, all of them, their grandfather were born there. They stayed there since they were...in short, they don't know ... most of them don't know, their places. There are buildings ... the beautiful ones are even better than the ones [name withheld] has in his village. Some of the landlords there own them, and you came one day, say that the place is a ghetto? You want to clear it and build nice houses. How can you tell that type of story?"

Despite subsisting positive arguments and optimisms, Enugu State government and most of its ministries, agencies, and parastatal, including MLUD are yet to rescind from treating UgboOkonkwo as a 'slum'. Respondent 5 had complained that, over the years, most of them have tried without success to register their plots or approve their building plans with both ECTDA and MLUD. When this question was raised with Respondent 9 (a chief planning executive in MLUD), he did not hesitate to confirm the point with some explanations:

"But what I think you may also need to know is that this office has never approved any building plan for anybody within Ugbo-Okonkwo, unless the person had acquired a plot of land, you know, that comprised within that scheme. So that if you don't have a plot number, we don't give you approval in an unapproved scheme."

The dilemma of stigmatising Ugbo-Okonkwo as a 'slum' coupled with the double deadlocks of denying residents both land registration and property approval are among the main cruxes confronting the residents. Such set-backs go to portray earlier struggles and successes as a mere pyrrhic victory. However, in the eyes of the community people, the palpable reprieve and fragile hopes achieved somehow remain undiminished. For instance, Respondent 5 himself had breathed a sigh of relief and exclaimed "I believe it is over...it is over by God's grace". True 
to this belief, after the court order, tensions began to wane in the community until relative peace returned.

With the exit of Sullivan Chime Administration in 29 May, 2015 and subsequent reappointment of another Managing Director of ECTDA, repercussions of the eviction notice of Friday, January 30, 2014 appear to have fizzled out. In fact, neither has any official explanations been advanced for the agency's renewed calm posture nor any disclosures as to whether the planned Ugbo-Okonkwo clearance was postponed or abandoned altogether. Equally, neo-customary holdings of community residents are yet to be regularised, and negative toponyms often alluded to this customary community appear to have stuck indelibly. Are there prospects that this community might still face another eviction threat in the future? Regrettably, there are hardly any sufficient guarantees and/or proofs that Ugbo-Okonkwo or other customary communities will not be evicted in the future. Although customary tenure is recognised by both the LUA1978 and the Constitution of the Federal Republic of Nigeria (1999) coupled with its wide acceptance among the general public, (neo-)customary titles are considered to be in 'contemptible inferior status' relative to their statutory equivalents (Nwauche, 2010, p. 62). Just like Tagliarino et al. (2018) has uncovered in Lagos, Nigeria, statutory recognitions accorded the customary tenure do not equate exactly in practice as in the current case. And so, the cycle of conflict might someday begin all over again, confirming 'a state of impermanence' in which customary communities and landholders are forced to live (Morrison, 2017, p. 26).

\section{Conclusion}

With rapid expansion of many cities in Nigeria and Africa at large, we argued at the beginning of this article that adjoining peri-urban areas are facing displacements associated with continuous attritions and substitutions of customary tenure regimes by its statutory substitutes. In exploring this phenomenon and its repercussions, a community case study serves as a prism for deciphering inherent clashes, politics and inherent power relations, as well as diverse countervailing tactics and grassroots resistance. Overall, our findings suggest that periurbanisation is consequential to displacement risks confronting customary landholders and communities, which either emanates from government expropriations or market forces, or a combination of the two events. Affected individual and communities are habitually poised to defend their customary lands, prized by most of them as cultural heritage and livelihood support, against un-negotiated and un-settled expropriations, and undue (land) market 
pressures. Court orders, rights litigations, and other resistance tactics, like street protests, appeals to traditional authorities, prayers for divine intervention, etc., have proved expedient in halting - and/or even delaying - forced displacement for protracted periods. Yet, recent experiences in Nigeria have shown that such delays often amount to postponing the evil day. As this case study has demonstrated, peri-urban communities and poor residents in many expanding capital cities in Nigeria will remain at the mercy of government and market forces. This is likely to continue until appropriate amendments are made to the LUA-1978 in ways that ensure, among other things, legitimisation/registration of customary rights without compromising prompt and adequate compensation and/or resettlement.

Amidst ensuing protests and power plays, interested parties often exploit intrinsic cracks in plural tenure and segregated planning systems to either promote or impede displacements. Such cracks often come to the fore not only when written codes of statutory tenure (and other urban laws) are pitted against oral codes of customary tenure, but also with concurrence of multiple interfaces vis-à-vis government/traditional authorities, formal/informal schemes, as well as designed/contrived planning forms or settlement formations. Winners and losers emerge as a consequence, with the rich and powerful almost certainly beating the system to have their way. One enduring lesson here is that, unlike previously thought, peri-urban areas are politically charged spaces, in which developmentalist visions of urban progress are largely misconstrued. Prior attempts that perceive peri-urbanisation (or urbanisation, in general) in benign and nonthreatening terms, for example, 'quiet encroachment', appear to overlook minute details of actual 'changes on the ground' like urbanisation-induced attritions/substitutions of customary tenure regimes, land dispossessions and consequent struggles. The current evidence, in concert with related studies, give hint for this under-scrutinised fault-line of urbanisation that ostensibly connects demise of customary tenure, loss of cultural property, livelihoods and rights disempowerment with food insecurity and poverty. Further research is needed in order to expound these linkages in more details. As Nigerian cities continue to expand without integrated planning measures in place to harness potentialities of the urban, peri-urban, perirual, and rural zones, commensurate governance arrangements necessary to renegotiate novel cooperation are forfeited. Customary communities and peri-urban poor often fall between the cracks in ensuing haphazard legal, governance, and planning crises, ending up as hapless victims of urbanisation-induced displacements. 
Moreover, current findings have cross-cutting and multi-layered implications for policy and urban planning. They re-emphasise the imperative for legal reforms, incorporating codification and transcription of customary rules from oral to written forms as a necessary prerequisite for grounding customary tenure and alternative planning practices. Amendments to the LUA-1978 and other urban laws with remit for better accommodation and acceptance of customary tenure laws/practices are long overdue. A truly national land law ought to take on board pro-poor legal empowerment systems that endorse a 'continuum of land rights', ranging from verifiable and documented occupancies/land uses to others that are less formalised and individualised. Such a bundle of rights falls in place with integrated planning and governance solutions, and when combine with other corresponding measures will hopefully stem the tide of urbanisationinduced displacements in Nigerian cities. This points to an effective way to fast track the achievement of UN-Habitat's Sustainable Development Goal No. 11 of making affected cities and human settlements more inclusive, safe, resilient and sustainable.

\section{Acknowledgement}

The authors are grateful to the Editors and three anonymous reviewers for their insights and valuable contributions to final outcome of this article. It goes without saying that all remaining errors are ours. The UK DFID supported the research under its Urban Research Nigeria programme (2016-2017). We equally received a grant from Dutch Ministry of Foreign Affairs to present the initial article idea at the Third conference of the Law and Development Research Network (LDRN), "INTERFACES" (19-21 September 2018) at the Van Vollenhoven Institute, Leiden University, the Netherlands.

\section{References}

Agheyisi, J. E. (2019a). Inter-communal land conflicts in Benin City, Nigeria: Exploring the root causes in the context of customary land supply. Land Use Policy, 83, 532-542.

Agheyisi, J. E. (2019b). Informal Land Delivery and Tenure Security Institutions in Benin City, Nigeria. In Urban Forum, 31, 1-20.

Alden Wily, L. (2011). Customary Land Tenure in the Modern World Rights to Resources in Crisis: Reviewing the Fate of Customary Tenure in Africa. Brief No. 1. Washington, DC: The Rights and Resources Initiatives. Retrieved from: https://dlc.dlib.indiana.edu/dlc/bitstream/handle/10535/7713/customary\%20land\%20tenure\% 20in\%20the\%20modern\%20world.pdf? sequence $=1$

Alden Wily, L. (2016). Customary tenure: remaking property for the 21 st century. In M. Graziadei and L. Smith (Eds.) Comparative Property Law: Global Perspectives (pp. 458478), Cheltenham: Edward Elgar.

Alden Wily, L. (2018a). Collective land ownership in the 21st century: Overview of global trends. Land, 7(2), 68. DOI: 10.3390/land7020068 
Alden Wily (2018b) Community Property in Africa. Brief No. 2. The Rights and Resources Coalition. Retrieved from:

https://www.forestpeoples.org/sites/default/files/documents/Brief\%202\%20\%20Community\%20Property\%20in\%20Africa.pdf

Allen, A. E., Davila, J., Hofmann, P., \& Brown, D. (2015). Topic guide: Building reciprocal rural-urban linkages through infrastructure investment and development. London: UK Department of International Development. DOI: http://dx.doi.org/10.12774/eod_tg.allenaetal

Arku, G. (2009). Rapidly growing African cities need to adopt smart growth policies to solve urban development concerns. Urban Forum, 20(3), pp. 253-270.

Bartels, L. E. (2019). Peri-urbanization as "Quiet Encroachment" by the middle class. The case of P\&T in Greater Accra. Urban Geography, 1-26.

Berdegué J. A. and Proctor F. J. with Cazzuffi C., 2014. Inclusive Rural-Urban Linkages. Working Paper Series $N^{\circ}$ 123. Working Group: Development with Territorial Cohesion. Territorial Cohesion for Development Program. Rimisp, Santiago, Chile.

Berrisford, S. \& MacAuslan, P. (2017). Reforming Urban Laws in Africa: A Practical Guide.

Boone, C. (2019). Legal empowerment of the poor through property rights reform: Tensions and trade-offs of land registration and titling in sub-Saharan Africa. The Journal of Development Studies, 55(3), 384-400.

Cabannes, Y., Yafai, G. S., \& Johnson, C. (2010). How people face evictions. The Building and Social Foundation. Project Report. Retrieved from:

https://www.ucl.ac.uk/bartlett/development/sites/bartlett/files/how people face evictions en g.pdf (23 November 2010).

Chimhowu, A. (2019). The 'new' African customary land tenure. Characteristic, features and policy implications of a new paradigm. Land Use Policy, 81, 897-903.

Chineme, L., Ifenancho, I., Kurth, H. \& Zellweger, A. (2005). Project "New Haven" Enugu/Nigeria Phase 3b. Final Report of the Workshop that took place August to October 2005 at Burgdorf CH, Switzerland. University of Nigeria, Enugu Campus, Nigeria and Bern University of Applied Sciences for Architecture, Civil and Wood Engineering, Burgdorf, Switzerland.

Dadashpoor, H., \& Somayeh, A. (2019). Land tenure-related conflicts in peri-urban areas: A review. Land Use Policy, 85, 218-229.

Deveaux, M. (2018) Poor-Led Social Movements and Global Justice. Political Theory, 46(5) $698-725$.

Dike, A. A. (1983). Land tenure in Igboland. Anthropos, 78(5/6), 853-71.

Duxbury, N., Hosagrahar, J., \& Pascual, J. (2016). Why must culture be at the heart of sustainable urban development? Agenda 21 for Culture. Retrieved from: 
https://estudogeral.uc.pt/bitstream/10316/44016/1/Why\%20must\%20culture\%20be\%20at\%2 0the\%20heart\%20of\%20sustainable\%20urban\%20development.pdf

Edike, T. (2014, February 7). Enugu to demolish 5 slums in capital city ...Court restrains govt. Vanguard Newspaper (Nigeria). Retrieved from:

https://www.vanguardngr.com/2014/02/enugu-demolish-5-slums-capital-city-court-restrainsgovt/.

Elmqvist, T., Fragkias, M., Goodness, J., Güneralp, B., Marcotullio, P. J., McDonald, R. I., ... \& Wilkinson, C. (Eds.). (2013). Urbanization, biodiversity and ecosystem services: challenges and opportunities: a global assessment. Springer.

Enugu State Government (Nigeria) (2012). Enugu State Vision 4: 2020. Enugu. Retrieved from: https://enugustate.gov.ng/wp-content/uploads/2017/03/EMTDP-2010-2013.-FinalVersion-main4.pdf

Foucault, M. (1990). The history of sexuality: An introduction, volume I. Trans. Robert Hurley. New York: Vintage.

Glaeser, E. L. (2014). A World of Cities: The Causes and Consequences of Urbanization in Poorer Countries. Journal of the European Economic Association, 12(5), 1154-99.

Haase, D., Güneralp, B., Dahiya, B., Bai, X., \& Elmqvist, T. (2018). Global Urbanization. In Elmqvist, T., Bai, X., Frantzeskaki, N., Griffith, C., Maddox, D., McPhearson, T., ... \& Harvey, D. (2007). Neoliberalism as Creative Destruction. Annals of the American Academy of Political and Social Science, 610, 22-44.

Ikejiofor, C. U. (2006). Equity in informal land delivery: insights from Enugu, Nigeria, Land Use Policy, 21, 448-59.

Khan, D., \& Karak, A. (2019). Urban development by dispossession: planetary urbanization and primitive accumulation. Studies in Political Economy, 1-24. DOI:

10.1080/07078552.2018.1536366

Lamond, J., Awuah, B. K., Lewis, E., Bloch R. and Falade, B. J. (2015). Urban Land, Planning and Governance Systems in Nigeria. Urbanisation Research Nigeria Research Report. London: ICF International. Retrieved from:

http://eprints.uwe.ac.uk/31292/1/URN\%20Theme\%20D\%20Planning\%20Report\%202015\% 20FINAL.pdf

Leedy, P. D., \& Ormrod, J. (2010). E. 2010. Practical Research: Planning and Design (9 $9^{\text {th }}$ Edition). Boston, Pearson Educational International.

Mabin, A., Butcher, S., \& Bloch, R. (2013). Peripheries, sub-urbanisms and change in subSaharan African cities. Social Dynamics, 39(2), 167-190.

Martiniello, G. (2019). Accumulation by Dispossession and Resistance in Uganda. In Moyo, S., Jha, P., \& Yeros, P. (Eds) Reclaiming Africa (pp. 183-201). Springer, Singapore. 
Master Plan for Enugu (1979). Phase 2: Detailed Data Analysis, Concept Eco-design International, Enugu and Cambridge, Massachusetts.

McAuslan, P. (2006). Legal Pluralism as a Policy Option: Is it Desirable? Is it Doable? CAPRi Policy Brief, 9.

Morrison, N. (2017). Struggling for the Right to Be Recognized: The Informal Settlement of Old Fadama, Accra, Ghana. In Brickell, K., Arrigoitia, M. F., \& Vasudevan, A. (Eds). Geographies of Forced Eviction (pp. 25-45). Palgrave Macmillan, London.

Nwauche, E. S. (2010). The constitutional challenge of the integration and interaction of customary and the received English common law in Nigeria and Ghana. Tul. Eur. \& Civ. $L F, 25,37-63$.

Onyebueke, V. U., \& Ikejiofor, C. (2017). Neo-customary land delivery systems and the rise of community-mediated settlements in peri-urban Enugu, Nigeria. International Development Planning Review, 39(3), 319-340.

Onyebueke, V. U., \& Ndukwu, R. I. (2017). Neo-customary Turn in Urban Land/Settlement Delivery and the Sprawl Question in Peri-urban Enugu, Nigeria. Trialog: A Journal of Planning and Building in the Global Context. 128, 1(2017), 35-39

Onyebueke, V., Walker, J., Lipietz, B. Ohaeri, V. and Ujah, O. (2019) Evicting the Poor in the 'Overriding Public Interest': Crisis of Rights and Interests, and Anti-Planning in Nigerian Cities. In Albert, I. O. and Lawanson, T. (eds.) Urban Crisis and Management in Africa: A Festschrift for Prof. Akin Mabogunje. Austin Texas: Pan-African University Press.

Oshio, P. E. (1990). The indigenous land tenure and nationalisation of land in Nigeria. $B C$ Third World LJ, 10, 43-62.

Otto J. M. \& Hoekema, A. (2012) Legalising Land Rights, Yes But How? An Introduction. In Jan Michiel Otto \& André Hoekema (Eds.) Fair Land Governance: How to legalise Land Rights for Rural Development (pp. 7-30). Leiden: Leiden University Press.

Peters, T. \& Arum C. R. (2014, March 13). Five 'slum' settlements in Enugu for demolition. Advocate Newspaper, Enugu. Retrieved from:

https://issuu.com/theadvocatengr/docs/the_advocate_36th_edition_republish ()

Price, S. (2015). A no-displacement option? Rights, risks and negotiated settlement in development displacement. Development in Practice, 25(5), 673-685.

Sawyer, L. (2014). Piecemeal urbanisation at the peripheries of Lagos. African studies, 73(2), 271-289.

Sherman, Z. (2016). Primitive Accumulation in the Cultural Commons. Review of Radical Political Economics, 48(1), 176-88.

Tagliarino, N. K., Bununu, Y. A., Micheal, M. O., De Maria, M., \& Olusanmi, A. (2018). Compensation for Expropriated Community Farmland in Nigeria: An In-Depth Analysis of the 
Laws and Practices Related to Land Expropriation for the Lekki Free Trade Zone in Lagos. Land, 7(1), 1-38.

Turok, I. (2016) Getting urbanization to work in Africa: the role of the urban landinfrastructure-finance nexus. Area Development and Policy, 1(1), 30-47, DOI: 10.1080/23792949.2016.1166444

Ubink, J. M. (2007). Tenure security: Wishful policy thinking or reality? A case from peri-urban Ghana. Journal of African Law, 51(2), 215-248.

UN DESA, United Nations: Department of Economic and Social Affairs (2018) World Urbanization Prospects: The 2018 Revision, Key facts. New York: UN. Retrieved from: https://population.un.org/wup/Publications/

UN-Habitat 2016. Goal 11: Make Cities Inclusive, Safe, Resilient and Sustainable. Retrieved from: www.un.org/sustainabledevelopment/cities/

Vij, S., Narain, V., Karpouzoglou, T., \& Mishra, P. (2018). From the core to the periphery: Conflicts and cooperation over land and water in peri-urban Gurgaon, India. Land Use Policy, 76, 382-390.

Vinthagen, S., \& Johansson, A. (2013). Everyday resistance: Exploration of a concept and its theories. Resistance Studies Magazine, 1(1), 1-46.

Wang, H., He, Q., Liu, X., Zhuang, Y., \& Hong, S. (2012). Global urbanization research from 1991 to 2009: A systematic research review. Landscape and Urban Planning, 104(3-4), 299309.

Wiersma, L. L. (2004). Indigenous lands as cultural property: A new approach to indigenous land claims. Duke University Law Journal, 54, 1061. 